\title{
Hematological, Metabolic, and Endocrine Effects of Feeding Vitamin A and Lactoferrin in Neonatal Calves*
}

\author{
C. Muri, ${ }^{1}$ T. Schottstedt, ${ }^{1}$ H. M. Hammon, ${ }^{1}$ E. Meyer, ${ }^{2}$ and J. W. Blum ${ }^{1}$ \\ ${ }^{1}$ Division of Animal Nutrition and Physiology, Institute of Animal Genetics, \\ Nutrition and Housing, Vetsuisse Faculty, University of Berne, 3012-Berne, Switzerland \\ ${ }^{2}$ Department of Physiology, Biochemistry and Biometrics, Faculty of Veterinary Medicine, \\ Ghent University, Merelbeke, Belgium
}

\begin{abstract}
There are reports of important interactions among vitamin A, lactoferrin (Lf), and components of the insulin-like growth factor (IGF) system. Newborn calves are deficient in vitamin $\mathrm{A}$ and have a low Lf status. Colostrum contains vitamin A, Lf, and members of the IGF system, including IGF binding proteins (IGFBP), and these compounds may exert mutual interactions in neonatal calves. Effects of feeding different amounts of vitamin A and Lf on hematological, metabolic, and endocrine traits during the first $5 \mathrm{~d}$ of life were studied in neonatal calves. Calves were fed a milk-based formula without $(\mathrm{F})$ or with added vitamin $\mathrm{A}\left[\mathrm{F}_{\mathrm{A}} ; 351\right.$, 402,490 , and $490 \mu \mathrm{mol} / \mathrm{kg}$ dry matter (DM) on d 1, 2, 3 , and 4 , respectively], $\mathrm{Lf}\left(\mathrm{F}_{\mathrm{L}} ; 3850,1990,660\right.$, and 660 $\mathrm{mg} / \mathrm{kg} \mathrm{DM}$ on d $1,2,3$, and 4 , respectively), or vitamin $\mathrm{A}+\mathrm{Lf}\left(\mathrm{F}_{\mathrm{AL}}\right)$ and colostrum $(\mathrm{C})$. Blood samples were taken preprandially on $\mathrm{d} 1$ to 5 and postprandially on $\mathrm{d} 1,2$, and 4 for the study of hematological, metabolic, and endocrine traits. As intestinal absorption of $\mathrm{Lf}$ in formula-fed calves was obviously lower than in colostrum-fed calves, Lf supplementation did not influence the metabolic and endocrine status. Plasma vitamin A concentrations increased from $d 1$ to 5 in $\mathrm{F}_{\mathrm{A}}, \mathrm{F}_{\mathrm{AL}}$, and $\mathrm{C}$, but remained low in $\mathrm{F}$ and $\mathrm{F}_{\mathrm{L}}$. Addition of vitamin A to $\mathrm{F}$ affected concentrations of vitamin A from $\mathrm{d} 2$ to 5 ; hemoglobin and triglycerides on $\mathrm{d} 3$; and tended to influence IGFBP-3 levels on d 5. On d 1, preprandial insulin concentrations in $\mathrm{F}$ and $\mathrm{F}_{\mathrm{L}}$ were higher than those in $\mathrm{F}_{\mathrm{A}}$ and $\mathrm{F}_{\mathrm{AL}}$ and growth hormone concentrations on $\mathrm{d} 3$ in $\mathrm{F}_{\mathrm{A}}$ were higher than in $\mathrm{F}_{\mathrm{AL}}$. In $\mathrm{C}$, plasma Lf concentrations increased on $\mathrm{d} 1$ and then decreased until d 5, whereas plasma urea and IGF-I concentrations remained stable. Compared with F-fed calves, Cfed calves had higher plasma concentrations of Lf from
\end{abstract}

Received June 11, 2004.

Accepted October 7, 2004.

Corresponding author: J. W. Blum; e-mail: juerg.blum@itz. unibe.ch.

*Part of a thesis of C. Muri for DMV, accepted by the Vetsuisse Faculty, University of Berne, June 2004. d 1 to 4 , higher concentrations of vitamin $\mathrm{A}$ on $\mathrm{d} 5$, higher concentrations of total protein from d 2 to 5 , higher concentrations of triglycerides on $\mathrm{d} 3$ and 4 , and higher concentrations of IGF-I on $\mathrm{d} 4$ and 5 , but lower urea concentrations on $\mathrm{d} 4$ and 5 and lower basal growth hormone concentrations than in $\mathrm{F}, \mathrm{F}_{\mathrm{L}}$, and $\mathrm{F}_{\mathrm{A}}$. In conclusion, metabolite and hormone concentrations were influenced by differences in feeding. Addition of vitamin A influenced concentrations of vitamin A, hemoglobin, and triglycerides and tended to affect IGFBP3 levels. Lactoferrin and vitamin A did not interact with respect to the IGF-I and IGFBP-3 status.

(Key words: vitamin A, lactoferrin, metabolism, neonatal calf)

Abbreviation key: $\mathbf{C}=$ colostrum, $\mathbf{F}=$ formula, $\mathbf{F}_{\mathbf{A}}=$ formula + vitamin A, $\mathbf{F}_{\mathbf{L}}=$ formula + lactoferrin, $\mathbf{F}_{\mathbf{A L}}=$ formula + vitamin A + lactoferrin, $\mathbf{G H}=$ growth hormone; IGFBP = insulin-like growth factor binding protein; IgG = immunoglobulin G; $\mathbf{L f}=$ lactoferrin; $\mathbf{T}_{\mathbf{3}}=$ 3,5,3'-triidothyronine.

\section{INTRODUCTION}

In neonates, including calves, marked and immediate adaptations of physiological functions are needed during the first days of life. Colostrum $(\mathbf{C})$ ingested immediately after birth is rich in nutritive and nonnutritive substances (Blum and Hammon, 2000; Blum and Baumrucker, 2002). Among bioactive components present in C, lactoferrin (Lf), vitamin A (specifically its metabolite, retinoic acid), and members of the IGF system [specifically IGF binding protein-3 (IGFBP-3)] are of interest because important interactions may exist with respect to their function in the bovine mammary gland (Baumrucker and Erondu, 2000). Interactions among Lf, vitamin A, and IGFBP-3 may be also of relevance for the neonatal calf. Lactoferrin is present in high amounts in C (Masson et al., 1966; Tsuji et al., 1990; Dawes et al., 2004). Milk Lf is absorbed in the digestive tract by neonatal calves and then appears in blood plasma, in the bile (Harada et al., 1999; Dawes et al., 2004), and in the cerebrospinal fluid (Taluker et al., 
2003). Beta-carotene, the precursor of retinol, is also present in high amounts in $\mathrm{C}$ of cows (Johnston and Chew, 1984; Blum et al., 1997), and the C intake ensures an adequate beta-carotene and retinol status in neonatal calves (Konermann and Abou El Fadle, 1966; Blum et al., 1997; Zanker et al., 2000). The IGF that are ingested with $\mathrm{C}$ appear to be active in the gastrointestinal tract, probably modified by IGFBP (Blum and Baumrucker, 2002). To the best of our knowledge, no report is available on effects of and interactions among vitamin A, Lf, and the IGF system in calves and neonates of other species. Based on these premises, we have tested in neonatal calves the hypothesis that vitamin A and Lf, ingested by neonatal calves, exert metabolic, endocrine, and hematological effects and that there are interactions between Lf and vitamin A especially with respect to the IGF-I and IGFBP-3 status. Using milkbased formulas $(\mathbf{F})$, effects of supplementation were compared with nonsupplemented conditions and with physiological conditions of calves fed C.

\section{MATERIALS AND METHODS}

Experimental procedures were approved by the Cantonal Committee for the Permission of Animal Experimentation (Granges-Paccot, Canton of Freibourg, Switzerland) and were supervised by the Federal Veterinary Office (Berne). Thirty-five male calves (22 Simmental $\times$ Red Holstein, 12 Holstein-Friesian, and 1 Red Holstein) were studied. Calves were born after normal pregnancy duration (285 \pm 1 d) between February and May 2003 at the Experimental Station (Posieux, Switzerland) and at neighboring farms. Two of these calves were twins and were allocated to 2 different groups. Calves were separated immediately after birth from their dam and kept on straw in individual boxes. Five experimental groups were created, each consisting of 7 calves. The F-fed group consisted of 1 Red Holstein calf and 6 Simmental $\times$ Red Holstein calves; the $\mathrm{F}+$ lactoferrin $\left(\mathbf{F}_{\mathbf{L}}\right)$ fed group consisted of 3 Holstein-Friesian and 4 Simmental $\times$ Red Holstein calves; the $\mathrm{F}+\operatorname{vitamin} \mathrm{A}\left(\mathbf{F}_{\mathbf{A}}\right)$ fed group consisted of 3 Holstein-Friesian and 4 Simmental $\times$ Red Holstein calves; the $\mathrm{F}+$ vitamin $\mathrm{A}+$ lactoferrin $\left(\mathbf{F}_{\mathbf{A L}}\right)$-fed group consisted of 3 HolsteinFriesian and 4 Simmental $\times$ Red Holstein calves; and the C-fed group consisted of 3 Holstein-Friesian and 4 Simmental $\times$ Red Holstein calves.

Colostrum was collected from cows of the Experimental Station (Posieux, Switzerland). Cows were milked twice daily, and $\mathrm{C}$ of milkings 1,3 , and 5 after parturition was stored separately in plastic bottles at $-20^{\circ} \mathrm{C}$. Individual pools of milkings 1,3 , and 5 were prepared at the beginning of the study and then stored in plastic bottles at $-20^{\circ} \mathrm{C}$ until used. Before feeding, C was warmed to $40^{\circ} \mathrm{C}$ and then fed immediately. Formulas were produced by UFA AG (Sursee, Switzerland) and consisted of calcium-caseinate (Emmi Milch AG, Lucerne, Switzerland), lactalbumin (Emmi Milch), lactose, and a vitamin and mineral premix that contained vitamin $A$ only if fed to groups $F_{A}$ and $F_{A L}$ (Provimi S.A., Cossonay-Gare, Switzerland). Formula powders were dissolved in water, and fat (49.7\% saturated fatty acids, $39.0 \%$ unsaturated fatty acids, $6.7 \%$ polyunsaturated fatty acids, $2.1 \%$ trans fatty acids, $2.5 \%$ water; \#763, Nutriswiss AG, Lyss, Switzerland) was added during the mixing procedure. The added fat contained no measurable amounts of vitamin A. Lecithin, as emulsifier, was added (emulsifier LO-1; UFA AG) as 3\% of the amount of fat. Formulas for d 1, 2, 3, and 4 were planned to contain comparable amounts of nutrients as C fed on d 1 (milking 1), 2 (milking 3), 3, and 4 (milking 5). Compositions and concentrations of ingredients of $\mathrm{C}$ and $\mathrm{F}$ are shown in Table 1.

Three milk-based formulas were fed on $\mathrm{d} 1,2$, and 3 that contained amounts of nutrients similar to those of $\mathrm{C}$ milkings 1 , 3, and 5, respectively. The $\mathrm{F}$ of $\mathrm{d} 3$ was also fed on $\mathrm{d} 4$. Calves fed $\mathrm{F}$ were fed a milk-based $\mathrm{F}$ that was not supplemented with vitamin $\mathrm{A}$ and Lf, whereas groups $F_{L}, F_{A}$, and $F_{A L}$ were fed the same $F$ in the same amounts as in group $\mathrm{F}$, but Lf, vitamin A, or vitamin A + Lf were supplemented, respectively. In group $\mathrm{F}_{\mathrm{L}}, 3850,1990,660$, and $660 \mathrm{mg} \mathrm{Lf} / \mathrm{kg} \mathrm{DM}$ were added to the $\mathrm{F}$ that was fed on $\mathrm{d} 1,2,3$, and 4 , respectively. In group $\mathrm{F}_{\mathrm{A}}, 351,402,490$, and $490 \mu$ mol vitamin $\mathrm{A} / \mathrm{kg} \mathrm{DM}$ were added to the $\mathrm{F}$ that was fed on $\mathrm{d} 1,2$, 3 , and 4 , respectively. In group $\mathrm{F}_{\mathrm{AL}}, 351,402,490$, and $490 \mu \mathrm{mol} / \mathrm{kg}$ of DM of vitamin A and 3850, 1990, 660, and $660 \mathrm{mg} / \mathrm{kg}$ of DM of Lf were added to the F that was fed on $\mathrm{d} 1,2,3$, and 4 , respectively. The $\mathrm{Lf}$ (\#10116702; DMV International, Veghel, The Netherlands) was of high purity (97\%), was dissolved in bidistilled water $(1 \mathrm{~g} / 20 \mathrm{~mL})$ for better handling, and was mixed in the $\mathrm{F}$ immediately before feeding. Vitamin A (retinol) was mixed during the production of the different F. Group C was the control group that was fed pooled $\mathrm{C}$ that contained vitamin $\mathrm{A}(49,61$, and $76 \mu \mathrm{mol} /$ $\mathrm{kg}$ of DM in milkings 1,3 , and 5, respectively) and Lf (2030, 1110, and $560 \mathrm{mg} / \mathrm{kg}$ of DM in milkings 1,3 , and 5 , respectively). Calves fed $\mathrm{C}$ were fed pooled $\mathrm{C}$ obtained from milkings 1,3 , and 5 (d 1, 2, and 3 of lactation, respectively) on the first $3 \mathrm{~d}$ of life, and $\mathrm{C}$ of milking 5 was fed on $\mathrm{d} 4$. All calves were fed for $4 \mathrm{~d}$, but not on d 5 (day of euthanasia). Total fed amounts of $\mathrm{F}$ and $\mathrm{C}$ were $6 \%$ BW on d $1,8 \%$ BW on d 2 , and $10 \%$ BW on d 3 and 4 . Calves were fed by bottle twice daily. To ensure that all calves received an equal amount of $\mathrm{F}$ or $\mathrm{C}$, calves with reduced appetite were, in addition, tubefed their planned amounts. 
Table 1. Composition of colostrum and formulas fed to neonatal calves.

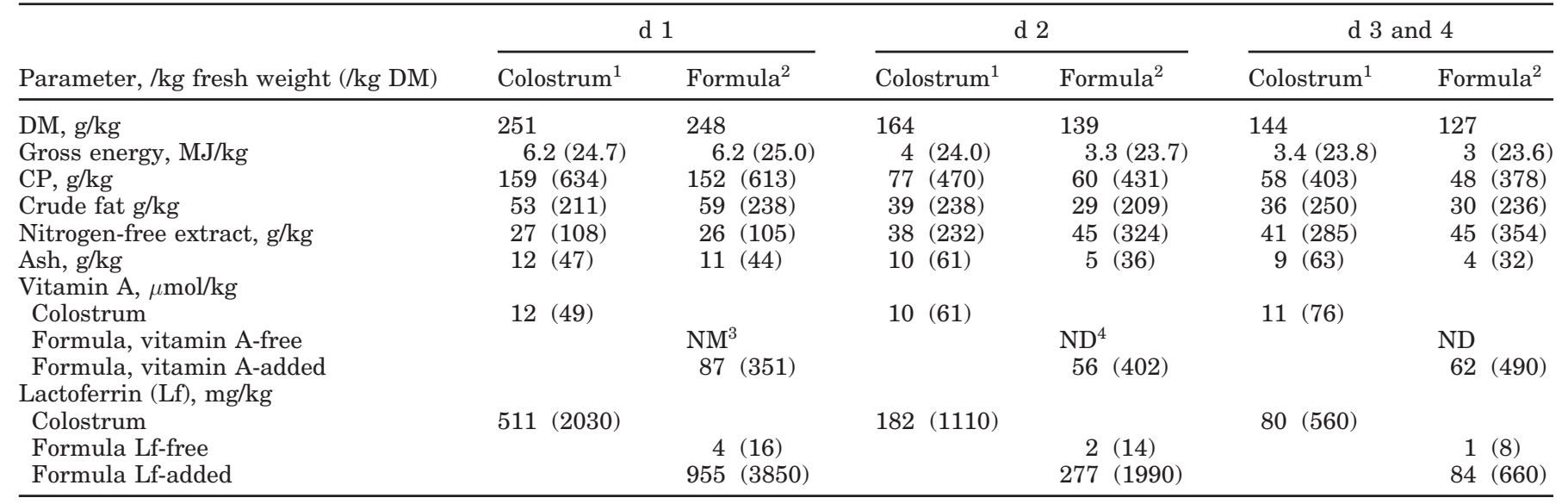

${ }^{1}$ Colostrum fed on $\mathrm{d} 1,2$, and 3 and 4 of life, respectively, were derived from pooled milkings 1,3 , and 5 , respectively.

${ }^{2}$ Formulas fed on $\mathrm{d} 1,2$, and 3 and 4 of life, respectively, were composed of calcium-caseinate (97, 238, and 334 g, respectively), lactalbumin (603, 250, and $64 \mathrm{~g}$, respectively), fat (180, 180, and 220, respectively), lactose (64, 275, and $322 \mathrm{~g}$, respectively), a vitamin and mineral premix (56, 57, and $59 \mathrm{~g}$, respectively), and lecithine $(30 \mathrm{~g} / \mathrm{kg}$ ). Fat (per $\mathrm{kg}$ ) contained 497, 390, 67, 21, and $25 \mathrm{~g}$ saturated, unsaturated, polyunsaturated, trans-fatty acids and water, respectively. The mineral premix (per $\mathrm{kg}$ ) contained calcium (186 g), magnesium (224 g), sodium (31 g), phosphorus (92 g), chlorine (48 g), iron (12 g), manganese $(8.1 \mathrm{mg})$, copper (1.6 mg), zinc $(7.8 \mathrm{mg})$, iodine $(0.03 \mathrm{mg})$, cobalt $(0.02 \mathrm{mg})$, and selenium $(0.02 \mathrm{mg})$. Vitamin E contents in colostrum milkings 1,3 , and 5 were 9,6 , and $7 \mathrm{mg} / \mathrm{kg}$, respectively, and in formulas fed on d 1, 2, and 3 and 4 were 294,138 , and $97 \mathrm{mg} / \mathrm{kg}$, respectively.

${ }^{3} \mathrm{NM}=$ Not measurable.

${ }^{4} \mathrm{ND}=$ Not done.

To protect against infections, $2 \mathrm{~g}$ of a bovine colostral Ig preparation (Gammaserin, Gräub AG, Berne, Switzerland) were injected subcutaneously before the first meal. Additionally, calves were fed chicken egg-derived Ig that contained high antibody titers against rotavirus and pathogenic $E$. coli type K 99 (Globigen 88; Lohmann Animal Health, Cuxhaven, Germany). Amounts per meal fed on d $1,2,3$, and 4 were $5,4,3$, and $2 \mathrm{~g}$, respectively. On $\mathrm{d} 2,3$, and 4 , calves were subcutaneously injected antibiotics (25 mg of Enrofloxacin $/ 10 \mathrm{~kg}$ of BW; Baytril 5\%; Bayer AG, Leverkusen, Germany).

\section{Health Status}

The health status was evaluated daily based on the following clinical traits: rectal temperature, heart rate, respiratory rate, behavior, nasal discharge, eye discharge, respiratory sounds, cough, appetite, fecal consistency, and navel and joint adspection. Navels were disinfected with Betadine (Mundipharma, Basle, Switzerland) after birth to protect calves from infection. The BW was determined preprandially on $\mathrm{d} 1,4$, and 5 .

\section{Blood Samples}

Blood samples were taken from a jugular vein with evacuated tubes on d 1 (day of birth), 2 , and 3 , and with a catheter on $\mathrm{d} 4$ and 5 . Tubes containing dipotassiumEDTA (1.8 g/L of blood) were used for the determination of pre- and postprandial values of glucose, triglycerides, NEFA, total protein, albumin, urea, insulin, and IGF$\mathrm{I}$ at 0,2 , and $4 \mathrm{~h}$ after the first, third, and seventh feedings and on $\mathrm{d} 3$ before feed intake, respectively, and for the determination of preprandial values of IGFBP-2 and -3 on $\mathrm{d} 5$ and of 3,5,3'-triidothyronine $\left(\mathbf{T}_{\mathbf{3}}\right)$ on $\mathrm{d} 1$, 2, 3, 4, and 5. Growth hormone $(\mathbf{G H})$ concentrations were measured in pre- and postprandial samples on $d$ 1 and 2 , in preprandial samples on $\mathrm{d} 3$ and 5 , and in 25 samples on d 4, taken before $(0 \mathrm{~h})$ and every $20 \mathrm{~min}$ after the morning feeding for $8 \mathrm{~h}$ for the evaluation of secretory patterns. Tubes were kept on crushed ice until centrifuged at $1000 \times g$ for $20 \mathrm{~min}$. Supernatants were aliquoted and stored at $-20^{\circ} \mathrm{C}$. A small amount of whole blood from preprandial samples on $\mathrm{d} 1$ and 5 was used for the determination of hematological traits and blood gases.

\section{Laboratory Analyses}

Blood analyses. Hematocrit, hemoglobin concentration, number of erythrocytes, number of leukocytes, segmented neutrophils, monocytes, lymphocytes, and thrombocytes were determined using an automatic analyzer (Cell-Dyn 3500; Abbott Diagnostic, Chicago, IL) at the Clinic of Large Animals and Horses, University of Berne, Berne, Switzerland. Numbers of eosinophils and basophils were only irregularly detectable. The $\mathrm{pH}$, $\mathrm{pO}_{2}, \mathrm{pCO}_{2}$, base excess, and bicarbonate $\left(\mathrm{HCO}_{3}\right)$ were 
measured in venous blood (i-STAT Corporation, East Windsor, NJ). Plasma concentrations of albumin, glucose, total protein, triglycerides, and urea were measured using kits (\#61051, \#61269, \#61602, \#61236, and \#61974, respectively) from Bio Mérieux, Marcy l'Etoile, France, and NEFA using a kit (\#994-75409) from Wako Chemicals, Neuss, Germany. Plasma insulin, GH, IGF$\mathrm{I}$, and $\mathrm{T}_{3}$ concentrations were measured by radioimmunoassays as previously described (Hadorn et al., 1997; Hammon and Blum, 1997, 1998). Plasma concentrations of IGFBP-2 and -3 were measured by ligand blots using ( $\left.{ }^{125} \mathrm{I}\right)$-labeled IGF-II, as described by Hammon and Blum (1997). Autoradiographs were scanned using software (Kodak Digital Science 1D Image Analysis; Eastman, Kodak CD, Rochester, NY).

Plasma Lf concentrations were measured with an ELISA kit (Bethyl, Montgomery, TX) specific for bovine Lf.

Plasma retinol concentrations were measured with a HPLC method with diode-array detection at the University of Ghent (Van Merris et al., 2002) adapted for calf plasma analysis.

Analyses in F, C, and fat. Samples of individual C pools from milkings 1,3 , and 5 and $\mathrm{F}$ for $\mathrm{d} 1,2$, and 3 were lyophilized to determine DM, CP (by Kjeldahl method), crude fat (direct extraction), and crude ash (after combustion at $550^{\circ} \mathrm{C}$ ) using standard procedures at the Swiss Federal Research Station (Agroscope Liebefeld-Posieux). Contents of nitrogen-free extract and gross energy were calculated. Vitamin A and vitamin $\mathrm{E}$ in $\mathrm{F}$ powders with vitamin $\mathrm{A}$ (for $\mathrm{d} 1,2$, and 3 ) and without vitamin A (for d 1 ) were analyzed at the Federal Research Station Agroscope Liebefeld-Posieux by HPLC as described by Söderhjelm and Andersson (1978), modified according to method 13.1.2 and 13.5.4, Methodenbuch III des Verbandes Deutscher Landwirtschaftlicher Untersuchungs- und Forschungsanstalten, VDLUFA-Verlag, Ergänzung 1988 and ISO-Methode $\mathrm{Nr}$ 34/SO 1 (Vitamin A determination by HPLC, May 15, 1986). Contents of vitamin A and $\mathrm{E}$ in colostrum were analyzed at the Federal Research Station Agroscope Liebefeld-Posieux according to Buetikofer and Bosset (1994). The Lf concentrations in F and C were measured with an ELISA Kit (Bethyl, Montgomery, TX) that was specific for bovine Lf. Colostrum and $\mathrm{F}$ samples were centrifuged at $14,000 \times \mathrm{g}$ for $15 \mathrm{~min}$, followed by removing the phase between the fat layer and precipitate that was subjected to analysis with ELISA.

\section{Statistical Procedures}

Values were expressed as means \pm SEM. For plasma concentrations of metabolic and endocrine traits, areas under concentration curves were computed for each day as measures of mean concentrations between 0 and 4 $\mathrm{h}$ after the morning meal. Areas under concentration curves, from which prefeeding values were substracted, were computed and served as measures of incremental or decremental changes $\left(\Delta_{0}\right.$ to $\left.4 \mathrm{~h}\right)$ to evaluate net effects of feeding. As data showed normal distribution, data of hematological, metabolic, and endocrine traits as well as of blood gases were evaluated using the RANDOM and REPEATED methods of the MIXED procedure (SAS, 1994). Separate models were applied for the evaluation of vitamin $\mathrm{A}$ and Lf effects in F-fed calves (model 1) and to compare F-fed groups with C-fed calves (model 2). Differences of preprandial and mean plasma concentrations during the whole experimental period of $5 \mathrm{~d}$ and for the calculation of postprandial effects on $d 1$, 2 , and 4 , respectively, were calculated in both models. Feeding of vitamin A, Lf, and C as well as time were used as fixed effects, and individual calves were used as random effects. For the evaluation of differences in Lf responses with regard to different supplementation of vitamin $\mathrm{A}$ and for the evaluation of differences in time pattern within vitamin A- and Lf-supplemented groups, interactions (vitamin $\mathrm{A} \times \mathrm{Lf}$, vitamin $\mathrm{A} \times$ time, and $\operatorname{Lf} \times$ time) were included in model 1 . Feeding and time differences were localized by Bonferroni $t$-test ( $P$ $<0.1$ for a trend and $P<0.05$ for significant difference). Incremental or decremental changes $\left(\Delta_{0 \text { to } 4 \mathrm{~h}}\right)$ of metabolites and hormones were evaluated using the RANDOM and REPEATED methods of the MIXED procedure (SAS, 1994). Episodic secretion of GH on d 4 (mean concentrations and basal concentrations) was analyzed (Merriam and Wachter, 1982). Group differences were analyzed by GLM, and differences were localized by Bonferroni $t$-test $(P<0.1$ for a trend).

\section{RESULTS}

\section{Feed Intake, BW, and Health Status}

The first feed intake after birth was within $4.1 \pm 0.4$ $\mathrm{h}$ and was not significantly different among groups. Total feed intake on an original matter basis was similar in the 5 groups, but, during the $4 \mathrm{~d}$, calves fed $\mathrm{C}$ received slightly higher amounts of DM, gross energy, $\mathrm{CP}$, crude fat, and ash and slightly lower amounts of nitrogen-free extract than F-fed calves. Formula-fed calves during the $4 \mathrm{~d}$ ingested $51.3 \mathrm{~g} \mathrm{DM}, 1.2 \mathrm{MJ}$ gross energy, $23.5 \mathrm{~g} \mathrm{CP}, 11.9 \mathrm{~g}$ crude fat, $14.2 \mathrm{~g}$ nitrogen-free extract, and $1.9 \mathrm{~g}$ ash $/ \mathrm{kg}$ BW. Calves of groups $\mathrm{F}_{\mathrm{A}}$ and $\mathrm{F}_{\mathrm{AL}}$ during the $4 \mathrm{~d}$ ingested on average $22.1 \mu \mathrm{mol} / \mathrm{kg}$ BW of vitamin $A$, whereas those in groups $F$ and $F_{L}$ did not ingest measurable amounts of vitamin $\mathrm{A}$. Calves in groups $\mathrm{F}_{\mathrm{L}}$ and $\mathrm{F}_{\mathrm{AL}}$ during the $4 \mathrm{~d}$ ingested on average $96 \mathrm{mg} \mathrm{Lf}$, whereas those in groups $\mathrm{F}$ and $\mathrm{F}_{\mathrm{A}}$ ingested 
Table 2. Preprandial hematological parameters on $d 1$ and 5 of calves fed with formula $(F)$, formula plus vitamin $A$ ( $F_{A}$ ), formula plus lactoferrin $\left(\mathrm{F}_{\mathrm{L}}\right)$, formula plus vitamin $\mathrm{A}$ and lactoferrin $\left(\mathrm{F}_{\mathrm{AL}}\right)$, or colostrum $(\mathrm{C})$. Values are means $(\mathrm{n}=4$ to 6$)$ and pooled SE.

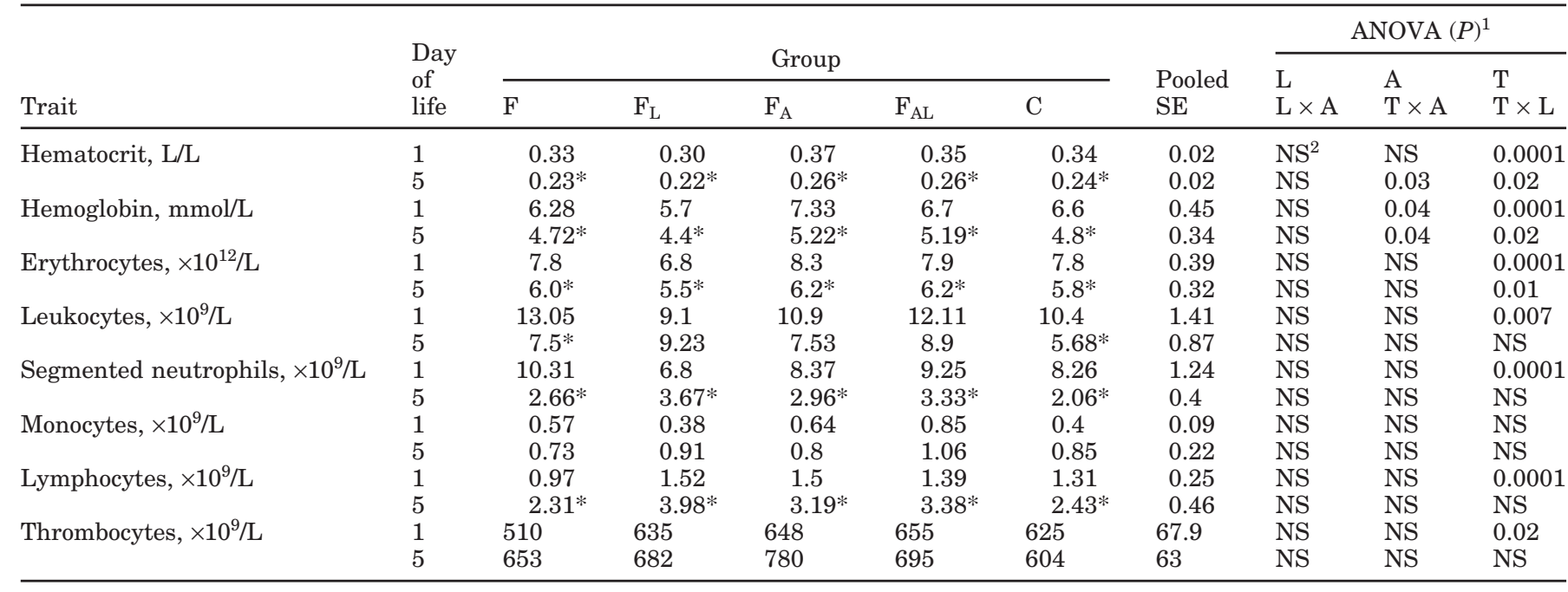

${ }^{1}$ Within formula-fed groups, $\mathrm{L}=$ lactoferrin effect, $\mathrm{A}=$ vitamin $\mathrm{A}$ effect, $\mathrm{T}=$ time effect (age), $\mathrm{L} \times \mathrm{A}=$ lactoferrin $\times$ vitamin $\mathrm{A}$ interaction, $\mathrm{T} \times \mathrm{A}=$ vitamin $\mathrm{A} \times$ time interaction, and $\mathrm{T} \times \mathrm{L}=$ time $\times$ lactoferrin interaction.

${ }^{2} P>0.05$.

*Values on d 5 are different from values on d $1(P<0.05)$.

$0.6 \mathrm{mg} \mathrm{Lf} / \mathrm{kg} \mathrm{BW}$. Colostrum-fed calves during the $4 \mathrm{~d}$ ingested on average $56.8 \mathrm{~g} \mathrm{DM}, 1.4 \mathrm{MJ}$ gross energy, $27.3 \mathrm{~g} \mathrm{CP}, 13.5 \mathrm{~g}$ crude fat, $12.9 \mathrm{~g}$ nitrogen-free extract, $3.3 \mathrm{~g}$ ash, $3.7 \mu \mathrm{mol}$ vitamin $\mathrm{A}$, and $61 \mathrm{mg} \mathrm{Lf} / \mathrm{kg} \mathrm{BW}$ (Table 1).

The BW after birth was similar for the 5 groups (45.9, 46.0, 46.3, 44.7, and $46.6 \mathrm{~kg}$ for groups $\mathrm{F}, \mathrm{F}_{\mathrm{L}}, \mathrm{F}_{\mathrm{A}}, \mathrm{F}_{\mathrm{AL}}$, and $\mathrm{C}$, respectively; mean for all groups: $45.9 \pm 0.8 \mathrm{~kg}$ ) and remained unchanged until d 5 (mean for all groups: $45.8 \pm 0.8 \mathrm{~kg})$.

The rectal temperature increased $(P<0.05)$ from $\mathrm{d}$ 1 (mean: $38.3 \pm 0.2^{\circ} \mathrm{C}$ ) to $\mathrm{d} 5$ (mean: $39.0 \pm 0.1^{\circ} \mathrm{C}$ ) in all groups. The heart rate decreased $(P<0.01)$ in groups $\mathrm{F}, \mathrm{F}_{\mathrm{L}}$, and $\mathrm{F}_{\mathrm{AL}}$ from $\mathrm{d} 1(173 \pm 11,168 \pm 12$, and $159 \pm$ $13 \times /$ min in groups $\mathrm{F}, \mathrm{F}_{\mathrm{L}}$, and $\mathrm{F}_{\mathrm{AL}}$, respectively) to $\mathrm{d} 5$ $\left(143 \pm 8,119 \pm 7\right.$, and $148 \pm 8 \times / \mathrm{min}$ in groups $\mathrm{F}, \mathrm{F}_{\mathrm{L}}$, and $\mathrm{F}_{\mathrm{AL}}$, respectively) but did not significantly change in groups $\mathrm{F}_{\mathrm{A}}$ and $\mathrm{C}(\mathrm{d} 1: 151 \pm 9$ and $159 \pm 11 \times /$ min, respectively; d 5: $155 \pm 8$ and $143 \pm 10 \times / \mathrm{min}$, respectively). Respiratory rate did not change during the experimental period (d 1: $46.4 \pm 2.29 \times / \mathrm{min}$; $d$ 5: $45.0 \pm 2.45 \times / \mathrm{min}$ ) in all 5 groups. Rectal temperatures, heart rates, and respiratory rates were not significantly different among groups. Calves were generally healthy, but fecal consistency was slightly watery from $\mathrm{d} 3$ on in $\mathrm{F}$-fed calves.

\section{Hematology, Blood pH, and Blood Gases}

Hematocrit was affected $(P<0.05)$ by time, by vitamin $\mathrm{A} \times$ time, and by $\mathrm{Lf} \times$ time interactions (Table 2 ) and decreased $(P<0.001)$ from $\mathrm{d} 1$ to 5 in all groups. The hemoglobin concentration was affected $(P<0.05)$ by vitamin $\mathrm{A}$, by time, by vitamin $\mathrm{A} \times$ time, and by $\mathrm{Lf}$ $\times$ time interactions and decreased $(P<0.001)$ from $d 1$ to 5 in all groups. The number of erythrocytes was affected $(P<0.05)$ by time and by time $\times$ Lf interaction and decreased $(P<0.001)$ from $d 1$ to 5 in all groups. The number of leukocytes was affected by time $(P<$ $0.001)$ and decreased $(P<0.05)$ in groups $\mathrm{F}$ and $\mathrm{C}$ from d 1 to 5 . The number of (segmented) neutrophils was affected by time $(P<0.001)$ and decreased $(P<0.05)$ from $\mathrm{d} 1$ to 5 in all groups. The number of lymphocytes was affected by time $(P<0.001)$ and increased $(P<$ 0.05 ) from $d 1$ to 5 in all groups. There were no significant changes in the number of monocytes and thrombocytes, and only the number of thrombocytes was affected by time $(P<0.05)$.

The $\mathrm{pH}$ was affected by time $(P<0.001)$ and increased $(P<0.05)$ from $\mathrm{d} 1$ to 5 in all groups (Table 3$)$. The $\mathrm{pO}_{2}$ decreased $(P<0.01)$ from $\mathrm{d} 1$ to 5 in group $\mathrm{F}_{\mathrm{AL}}$. The $\mathrm{pCO}_{2}$ was affected by time $(P<0.001)$ and decreased $(P<0.05)$ from $\mathrm{d} 1$ to 5 in groups $\mathrm{F}$ and $\mathrm{F}_{\mathrm{AL}}$. Base excess and bicarbonate concentrations were affected by time $(P<0.001$ and 0.005 , respectively) and increased $(P<$ 0.05 ) from $d 1$ to 5 in groups $F, F_{L}$, and $F_{A}$.

\section{Blood Metabolite and Hormone Concentrations}

Plasma Lf concentrations (Figure 1) on d 1 were affected by time $(P<0.001)$, by vitamin $\mathrm{A} \times$ time, and by vitamin $\mathrm{A} \times \mathrm{Lf}$ interactions $(P<0.05)$ and increased 
Table 3. Preprandial blood gases and $\mathrm{pH}$ on $\mathrm{d} 1$ and 5 of calves fed with formula (F), formula plus vitamin A $\left(F_{A}\right)$, formula plus lactoferrin $\left(F_{L}\right)$, formula plus vitamin $A$ and lactoferrin $\left(F_{A L}\right)$, or colostrum $(C)$ for all groups. Values are means ( $\mathrm{n}=4$ to 6 not 7 per group) and pooled SE.

\begin{tabular}{|c|c|c|c|c|c|c|c|c|c|c|}
\hline \multirow[b]{3}{*}{ Trait } & \multirow{3}{*}{$\begin{array}{l}\text { Day } \\
\text { of } \\
\text { life }\end{array}$} & \multirow{2}{*}{\multicolumn{5}{|c|}{ Group }} & \multirow[b]{3}{*}{$\mathrm{SE}$} & \multicolumn{3}{|c|}{ ANOVA $(P)^{1}$} \\
\hline & & & & & & & & & & \\
\hline & & $\mathrm{F}$ & $\mathrm{F}_{\mathrm{L}}$ & $\mathrm{F}_{\mathrm{A}}$ & $\mathrm{F}_{\mathrm{AL}}$ & $\mathrm{C}$ & & $\mathrm{L} \times \mathrm{A}$ & $\mathrm{T} \times \mathrm{A}$ & $\mathrm{T} \times \mathrm{L}$ \\
\hline \multirow[t]{2}{*}{$\mathrm{pH}$} & 1 & 7.21 & 7.22 & 7.21 & 7.25 & 7.22 & 0.02 & $\mathrm{NS}^{2}$ & NS & 0.001 \\
\hline & 5 & $7.34^{*}$ & $7.32 *$ & $7.33^{*}$ & $7.32^{*}$ & 7.30 * & 0.02 & NS & NS & NS \\
\hline \multirow{2}{*}{$\mathrm{pO}_{2}, \mathrm{kPa}$} & 1 & 3.5 & 3.9 & 3.4 & 3.3 & 4.0 & 0.3 & NS & NS & NS \\
\hline & 5 & 3.9 & 2.8 & 3.7 & $4.8^{*}$ & 4.0 & 0.4 & NS & NS & NS \\
\hline \multirow[t]{2}{*}{$\mathrm{pCO}_{2}, \mathrm{kPa}$} & 1 & 10.1 & 10.0 & 10.2 & 9.8 & 9.5 & 0.3 & NS & NS & 0.001 \\
\hline & 5 & $8.7 *$ & 9.7 & 9.2 & $8.5^{*}$ & 8.6 & 0.4 & NS & NS & NS \\
\hline \multirow[t]{2}{*}{ Base excess, mmol/L } & 1 & 2.2 & 3.5 & 3.0 & 4.3 & 1.5 & 1.5 & NS & NS & 0.001 \\
\hline & 5 & $8.8^{*}$ & $12 *$ & $10.8^{*}$ & 7.4 & 5.0 & 1.6 & NS & NS & NS \\
\hline \multirow{2}{*}{$\mathrm{HCO}_{3}, \mathrm{mmol} / \mathrm{L}$} & 1 & 30.2 & 31.2 & 31.0 & 31.7 & 29.2 & 1.25 & NS & NS & 0.004 \\
\hline & 5 & $34.7^{*}$ & $38.0^{*}$ & $36.7^{*}$ & 33.2 & 31.4 & 1.48 & NS & NS & NS \\
\hline
\end{tabular}

${ }^{1}$ Within formula-fed groups, $\mathrm{L}=$ lactoferrin effect, $\mathrm{A}=$ vitamin $\mathrm{A}$ effect, $\mathrm{T}=$ time effect (age), $\mathrm{L} \times \mathrm{A}=$ lactoferrin $\times$ vitamin $\mathrm{A}$ interaction, $\mathrm{T} \times \mathrm{A}=$ vitamin $\mathrm{A} \times$ time interaction, and $\mathrm{T} \times \mathrm{L}=$ lactoferrin $\times$ time interaction.

${ }^{2} P>0.05$.

*Values on d 5 are different from values on d $1(P<0.05)$.

after the first meal on $\mathrm{d} 1$ in group $\mathrm{F}(P<0.05)$ and in group $\mathrm{C}(P<0.001)$ and returned to basal concentrations $(P<0.05)$ in group $\mathrm{F}$ on $\mathrm{d} 2$ and in group $\mathrm{C}$ on $\mathrm{d}$ 4. Concentrations were higher $(P<0.05)$ in group $\mathrm{C}$ from $\mathrm{d} 1$ (within $2 \mathrm{~h}$ after the first meal) to $\mathrm{d} 4$ than in all F-fed calves and on $\mathrm{d} 1$ were higher $(P<0.001)$ in group $\mathrm{F}$ than in group $\mathrm{F}_{\mathrm{A}}$ at $4 \mathrm{~h}$ after the first meal.

Plasma vitamin A concentrations (Figure 2) were affected by time $(P<0.001)$, by vitamin A $(P<0.001)$, and by vitamin $\mathrm{A} \times$ time interactions $(P<0.001)$; were

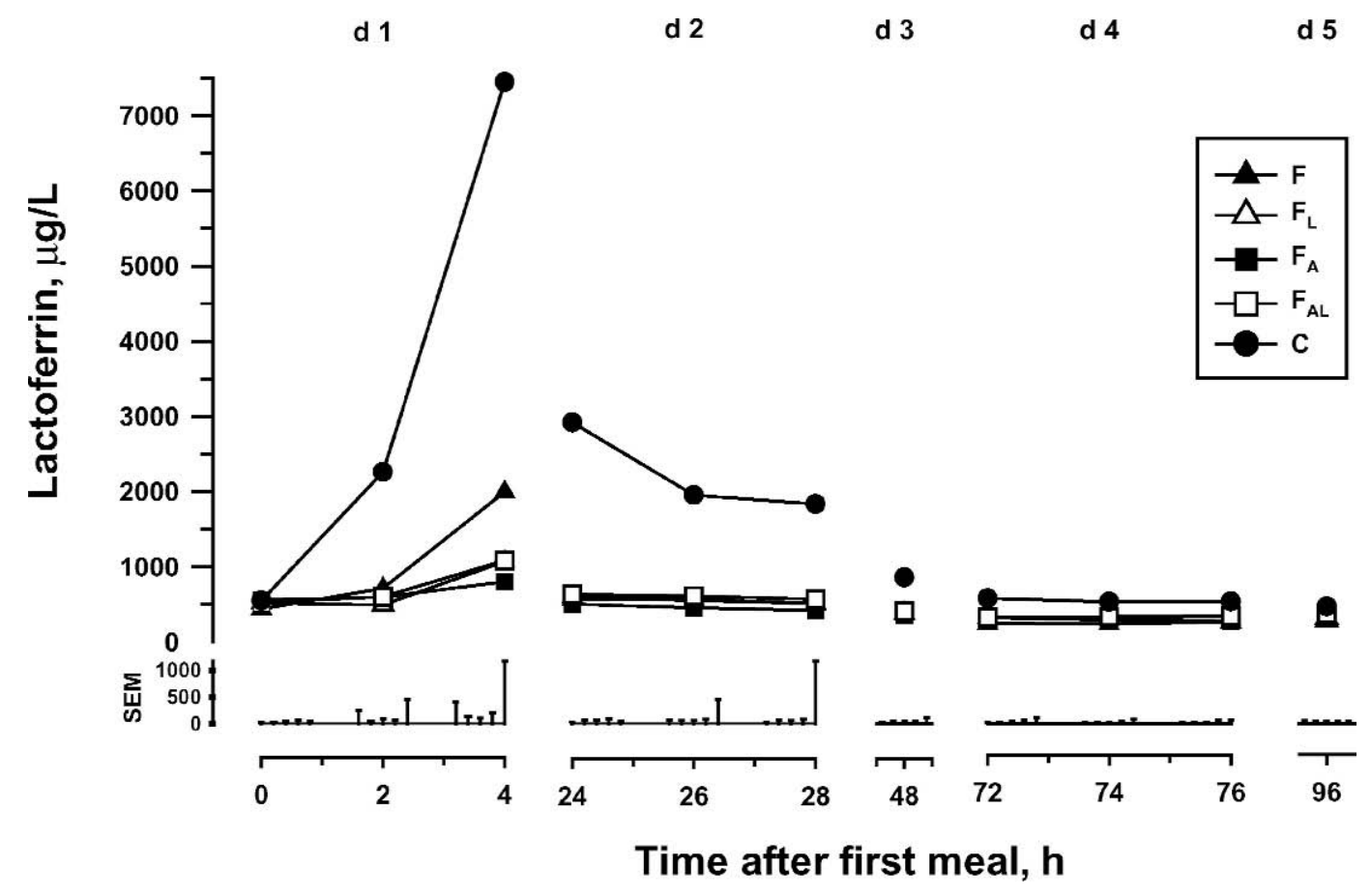

Figure 1. Plasma lactoferrin concentrations in calves fed with formula $(\mathrm{F}), \mathrm{F}$ plus vitamin $\mathrm{A}\left(\mathrm{F}_{\mathrm{A}}\right), \mathrm{F}$ plus lactoferrin $\left(\mathrm{F}_{\mathrm{L}}\right), \mathrm{F}$ plus vitamin $\mathrm{A}$ and lactoferrin $\left(\mathrm{F}_{\mathrm{AL}}\right)$, or with colostrum $(\mathrm{C})$. Blood samples were taken on d 1,2, 3, 4, and 5 shortly before feed intake and on $\mathrm{d} 1$, 2, and 4 additionally at 2 and $4 \mathrm{~h}$ after feed intake. Values are means; $\mathrm{n}=7$ per group. Standard error of means (SEM) of groups $\mathrm{F}, \mathrm{F}_{\mathrm{L}}, \mathrm{F}_{\mathrm{A}}, \mathrm{F}_{\mathrm{AL}}$, and $\mathrm{C}$ are shown on the bottom from the left to the right for $\mathrm{d} 1$ and 5 and of groups $\mathrm{F}, \mathrm{F}_{\mathrm{A}}$, and $\mathrm{C}$ on $\mathrm{d} 2,3$, and 4 . 


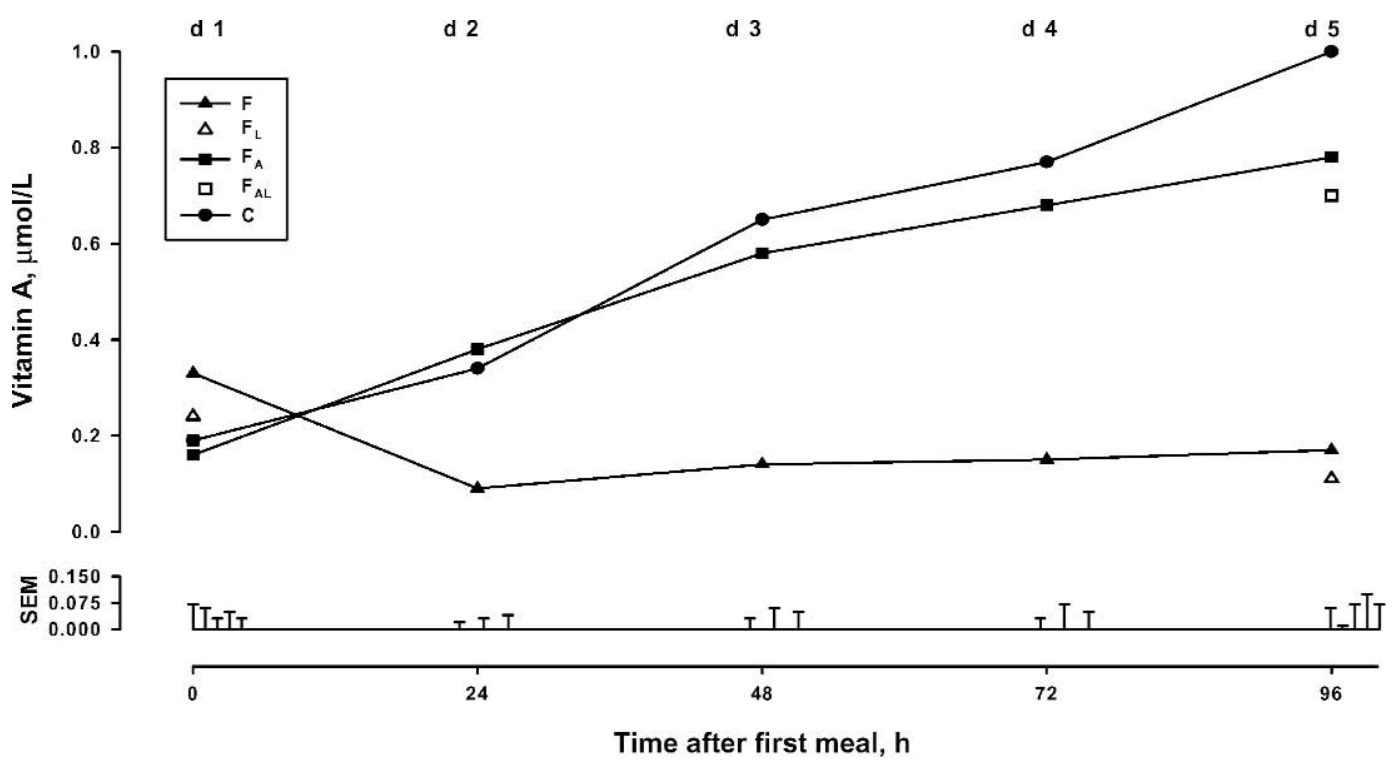

Figure 2. Plasma vitamin A (retinol) concentrations. Blood samples were taken shortly before feed intake on d 1, 2, 3, 4, and 5 in groups fed $\mathrm{F}$ (formula), $\mathrm{F}_{\mathrm{A}}$ (formula plus vitamin $\mathrm{A}$ ), and colostrum $(\mathrm{C})$ and only on $\mathrm{d} 1$ and 5 in groups fed $\mathrm{F}_{\mathrm{L}}$ (formula plus lactoferrin) and $\mathrm{F}_{\mathrm{AL}}$ (formula plus vitamin A and lactoferrin).

similar among groups on $\mathrm{d} 1$; increased $(P<0.001)$ from $\mathrm{d} 1$ to 5 in groups $\mathrm{F}_{\mathrm{A}}, \mathrm{F}_{\mathrm{AL}}$, and $\mathrm{C}(P<0.001)$; but remained low in groups $\mathrm{F}$ and $\mathrm{F}_{\mathrm{L}}$. Concentrations on $\mathrm{d}$ 5 were higher $(P<0.05)$ in group $\mathrm{F}_{\mathrm{A}}$ than in group $\mathrm{F}$, in group $\mathrm{F}_{\mathrm{AL}}$ than in group $\mathrm{F}_{\mathrm{L}}$, and in group $\mathrm{C}$ than in $\mathrm{F}$-fed groups. Concentrations in group $\mathrm{F}$ from $\mathrm{d} 2$ to 5 were lower $(P<0.001)$ than in groups $\mathrm{F}_{\mathrm{A}}$ and $\mathrm{C}$.

Plasma total protein concentrations (Figure 3) were affected by time $(P<0.001)$ and were similar among all F-fed groups on d 1. Preprandial concentrations increased $(P<0.001)$ in groups $\mathrm{F}, \mathrm{F}_{\mathrm{AL}}$, and $\mathrm{C}$ from $\mathrm{d} 1$ (on $\mathrm{d} 1$ at $4 \mathrm{~h}$ postprandially) to 5 and were always higher $(P<0.001)$ in group $\mathrm{C}$ than in $\mathrm{F}$-fed calves. Postprandial concentrations decreased $(P<0.01)$ on $\mathrm{d}$ 1 in all $\mathrm{F}$-fed calves, on $\mathrm{d} 2$ in groups $\mathrm{F}_{\mathrm{AL}}$ and $\mathrm{C}$, and on $\mathrm{d} 4$ in all groups $(P<0.001)$.

Plasma albumin concentrations (Table 4) were affected by time $(P<0.001)$ and decreased $(P<0.05)$ postprandially on $\mathrm{d} 1,2$ (in all groups except group F), and 4 in all groups (data not shown), but there were no significant group differences.

Plasma urea concentrations (Figure 4) were affected by time $(P<0.05)$; increased $(P<0.05)$ postprandially on 2 and 4 in groups $\mathrm{F}_{\mathrm{L}}, \mathrm{F}_{\mathrm{A}}$, and $\mathrm{F}_{\mathrm{AL}}$; and were higher on $\mathrm{d} 4$ and 5 in $\mathrm{F}$-fed calves $(P<0.05)$ than in group $\mathrm{C}$.

Preprandial plasma NEFA concentrations (Table 4) were affected by time $(P<0.001)$; decreased from $\mathrm{d} 1$ to 5 in all groups; and on d 1,2, and 4 , decreased $(P<$ 0.05 ) postprandially (data not shown), but there were no significant group differences.
Plasma triglyceride concentrations (Table 4) were affected by time $(P<0.001)$ and by vitamin A $(P<0.01)$. On d 3, preprandial concentrations were higher $(P<$ 0.05 ) in group $\mathrm{F}_{\mathrm{A}}$ than in group $\mathrm{F}$. Preprandial concentrations were lower $(P<0.05)$ on $\mathrm{d} 3$ and 4 in all $\mathrm{F}$-fed calves and on $\mathrm{d} 5$ in groups $\mathrm{F}$ and $\mathrm{F}_{\mathrm{L}}$ than in group $\mathrm{C}$.

Plasma glucose concentrations (Table 4) were affected $(P<0.05)$ by time, by vitamin $\mathrm{A} \times$ time, and by $\mathrm{Lf}$ $\times$ time interactions. Preprandial glucose concentrations on $\mathrm{d} 4$ in group $\mathrm{F}$ and on $\mathrm{d} 5$ in all $\mathrm{F}$-fed calves were lower $(P<0.05)$ than in group C. On $\mathrm{d} 1$ in groups $\mathrm{F}_{\mathrm{A}}$ and $\mathrm{F}_{\mathrm{AL}}$ and on $\mathrm{d} 2$ and 4 in all groups, concentrations transiently increased postprandially $(P<0.05$; data not shown).

Plasma GH concentrations were affected by time $(P$ $<0.001)$ and by vitamin $\mathrm{A} \times$ time interactions $(P<$ 0.05 ). On d 3 (Table 5), preprandial concentrations were higher $(P<0.05)$ in group $\mathrm{F}_{\mathrm{A}}$ than in groups $\mathrm{C}$ and $\mathrm{F}_{\mathrm{AL}}$. Concentrations on $\mathrm{d} 1$ in group $\mathrm{F}$ increased $(P<0.05)$ after feed intake, and on $\mathrm{d} 2$ in groups $\mathrm{F}$ and $\mathrm{C}$, concentrations transiently increased $(P<0.05)$ at $2 \mathrm{~h}$ after feed intake and then decreased (data not shown). During the 8-h profile on d 4 (Figure 5), concentrations transiently increased $(P<0.1)$ after feed intake until $40 \mathrm{~min}$ in groups $\mathrm{F}_{\mathrm{L}}, \mathrm{F}_{\mathrm{A}}$, and $\mathrm{F}_{\mathrm{AL}}$ and then decreased $(P<0.1)$ in all $\mathrm{F}$-fed calves (except in group $\mathrm{F}_{\mathrm{L}}$ ), whereas concentrations remained low in group C. At $40 \mathrm{~min}$ after feed intake, $\mathrm{F}$-fed calves had higher $(P<0.1)$ concentrations than those of group C. Mean concentrations in group $\mathrm{F}_{\mathrm{A}}$ and basal mean concentrations in groups $\mathrm{F}, \mathrm{F}_{\mathrm{L}}$, and 


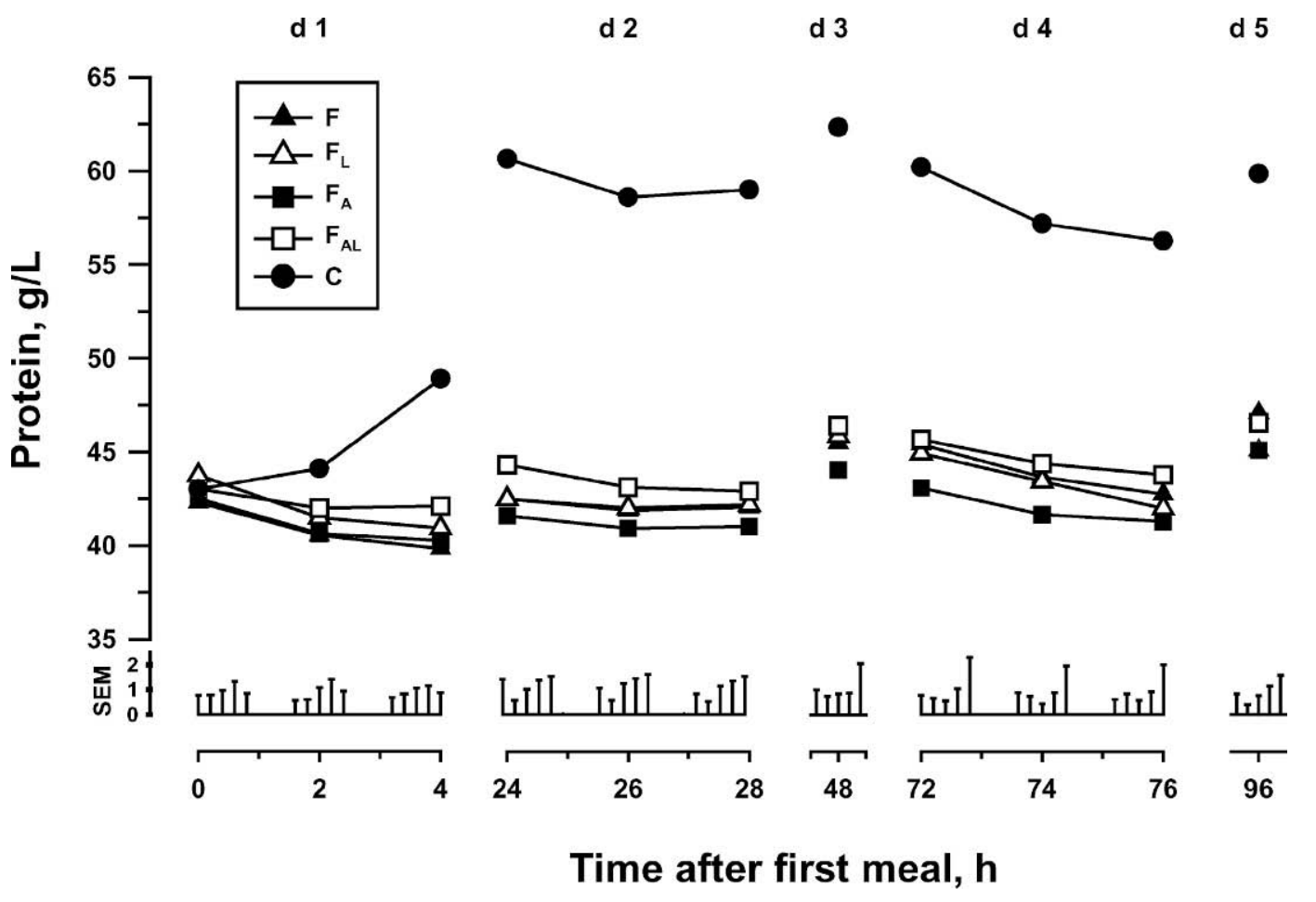

Figure 3. Plasma protein concentrations in calves fed with formula $(\mathrm{F}), \mathrm{F}$ plus vitamin $\mathrm{A}\left(\mathrm{F}_{\mathrm{A}}\right), \mathrm{F}$ plus lactoferrin $\left(\mathrm{F}_{\mathrm{L}}\right)$, $\mathrm{F}$ plus vitamin $\mathrm{A}$ and lactoferrin $\left(\mathrm{F}_{\mathrm{AL}}\right)$, or with colostrum $(\mathrm{C})$. Blood samples were taken on $\mathrm{d} 1,2,3,4$, and 5 shortly before feed intake and on $\mathrm{d} 1$, 2 , and 4 additionally at 2 and $4 \mathrm{~h}$ after feed intake. Values are means; $\mathrm{n}=7$ per group.

$\mathrm{F}_{\mathrm{A}}$ were higher $(P<0.05)$ than in group $\mathrm{C}$. In groups $\mathrm{F}$ and $\mathrm{F}_{\mathrm{L}}$, peak numbers and peak concentrations tended to be smaller $(P<0.1)$ than in group $\mathrm{C}$, and peak numbers were higher $(P<0.1)$ in group $\mathrm{F}_{\mathrm{AL}}$ than in group $\mathrm{F}$.

Preprandial insulin concentrations (Table 5) were affected by time $(P<0.01)$ and by vitamin $\mathrm{A} \times$ time interactions $(P<0.05)$. Concentrations on $\mathrm{d} 1$ in group $\mathrm{F}_{\mathrm{AL}}$ were lower $(P<0.05)$ than in group $\mathrm{C}$. On $\mathrm{d} 1$, concentrations in groups $\mathrm{F}$ and $\mathrm{F}_{\mathrm{L}}$ were higher $(P<0.05)$ than in groups $\mathrm{F}_{\mathrm{A}}$ and $\mathrm{F}_{\mathrm{AL}}$. Postprandial insulin concentrations on $\mathrm{d} 1$ in group $\mathrm{C}$ decreased $(P<0.05$; data not shown), but concentrations increased on $\mathrm{d} 2$ and 4 in all groups $(P<0.05$; data not shown).

Preprandial $\mathrm{T}_{3}$ concentrations (Table 5) were affected $(P<0.001)$ by time and decreased in all groups from $\mathrm{d}$ 1 to 5 .

Plasma IGF-I concentrations (Figure 6) were affected $(P<0.001)$ by time and by vitamin $\mathrm{A} \times$ time interactions. Vitamin A tended to influence IGF-I concentrations on d 2,4 , and $5(P<0.1)$. Concentrations decreased $(P<$ 0.01 ) from $\mathrm{d} 1$ to 5 in all $\mathrm{F}$-fed calves, but not significantly in group $\mathrm{C}$. On $\mathrm{d} 1$, concentrations in groups $\mathrm{F}$, $\mathrm{F}_{\mathrm{L}}$, and $\mathrm{F}_{\mathrm{A}}$ decreased postprandially $(P<0.01)$. On $\mathrm{d} 2$, group $\mathrm{F}_{\mathrm{AL}}$ had lower $(P<0.1)$ preprandial concentrations, but on $\mathrm{d} 5, \mathrm{~F}_{\mathrm{A}}$ had higher $(P<0.1)$ preprandial concentrations compared with group F. On d 3, concentrations in groups $\mathrm{F}, \mathrm{F}_{\mathrm{L}}$, and $\mathrm{F}_{\mathrm{AL}}$ were lower $(P<0.05)$ than in group C. Concentrations on $\mathrm{d} 4$ (except preprandial levels in groups $\mathrm{F}_{\mathrm{A}}$ and $\mathrm{F}_{\mathrm{AL}}$ ) and concentrations on d 5 in $\mathrm{F}$-fed calves were lower $(P<0.05)$ than in group C.

Levels of IGFBP-3 on d 5 (Table 6) in F-fed calves tended $(P<0.1)$ to be affected by vitamin A. Ratios of IGFBP-2 to IGFBP-3 were higher $(P<0.05)$ in group $\mathrm{F}$ than in group $\mathrm{C}$. There was a negative correlation $(\mathrm{r}=-0.58 ; P<0.001)$ between IGF-I concentrations and the IGFBP-2 to IGFBP-3 ratio, a positive correlation $(\mathrm{r}=0.55 ; P<0.001)$ between IGFBP-2 levels and the IGFBP-2 to IGFBP-3 ratio, and a negative correlation $(\mathrm{r}=-0.67 ; P<0.001)$ between IGFBP-3 levels and the IGFBP-2 to IGFBP-3 ratio. The IGF-I concentrations were positively correlated $(\mathrm{r}=0.42 ; P<0.01)$ with IGFBP-3 levels, but negatively $(\mathrm{r}=-0.37 ; P<0.05)$ with IGFBP-2 levels.

\section{DISCUSSION}

\section{Feeds and Feed Intake}

Decreases in DM, gross energy, CP, crude fat, and ash contents, but an increase in nitrogen-free extract content in $\mathrm{C}$ during the first days of lactation have also 
Table 4. Preprandial plasma concentrations of metabolic traits for the first $5 \mathrm{~d}$ of life of calves fed with formula $(F)$, formula plus vitamin $A\left(F_{A}\right)$, formula plus lactoferrin $\left(F_{L}\right)$, formula plus vitamin $A$ and lactoferrin $\left(\mathrm{F}_{\mathrm{AL}}\right)$, or colostrum $(\mathrm{C})$. Values are means $(\mathrm{n}=7$ per group; for urea in group $\mathrm{F} ; \mathrm{n}=6$ on $\mathrm{d} 2,3,4$, and 5 ) and pooled SEM.

\begin{tabular}{|c|c|c|c|c|c|c|c|c|c|c|}
\hline \multirow[b]{2}{*}{ Trait } & \multirow[b]{2}{*}{ Group } & \multirow[b]{2}{*}{ d 1} & \multirow[b]{2}{*}{ d 2} & \multirow[b]{2}{*}{ d 3} & \multirow[b]{2}{*}{ d 4} & \multirow[b]{2}{*}{ d 5} & \multirow[b]{2}{*}{ SEM } & \multicolumn{3}{|c|}{$\operatorname{ANOVA}(P)^{1}$} \\
\hline & & & & & & & & $\begin{array}{l}\mathrm{L} \\
\mathrm{L} \times \mathrm{A}\end{array}$ & $\begin{array}{l}\mathrm{A} \\
\mathrm{T} \times \mathrm{A}\end{array}$ & $\begin{array}{l}\mathrm{T} \\
\mathrm{T} \times \mathrm{L}\end{array}$ \\
\hline \multirow[t]{5}{*}{ Albumin, g/L } & $\mathrm{F}$ & 30.8 & 29.6 & 32.6 & 31.2 & 32.6 & 0.81 & $\mathrm{NS}^{2}$ & NS & 0.001 \\
\hline & $\mathrm{F}_{\mathrm{L}}$ & 32.5 & 31.1 & 32.9 & 31.6 & 32.5 & 0.59 & $\mathrm{NS}$ & NS & NS \\
\hline & $F_{A}$ & 30.9 & 29.9 & 31.0 & 30.6 & 32.1 & 0.82 & & & \\
\hline & $\mathrm{F}_{\mathrm{AL}}$ & 32.1 & 31.9 & 32.4 & 32.2 & 33.1 & 0.87 & & & \\
\hline & $\mathrm{C}$ & 31.9 & 30.0 & 31.6 & 32.1 & 33.2 & 0.70 & & & \\
\hline \multirow[t]{5}{*}{ NEFA, mmol/L } & $\mathrm{F}$ & 1.07 & 0.46 & 0.47 & 0.36 & 0.32 & 0.06 & NS & NS & 0.001 \\
\hline & $F_{L}$ & 0.76 & 0.43 & 0.58 & 0.40 & 0.41 & 0.08 & NS & NS & NS \\
\hline & $F_{A}$ & 0.98 & 0.45 & 0.42 & 0.39 & 0.37 & 0.07 & & & \\
\hline & $\mathrm{F}_{\mathrm{AL}}$ & 1.02 & 0.48 & 0.55 & 0.48 & 0.54 & 0.09 & & & \\
\hline & $\mathrm{C}$ & 0.86 & 0.49 & 0.52 & 0.40 & 0.33 & 0.08 & & & \\
\hline \multirow[t]{5}{*}{$\begin{array}{l}\text { Triglycerides, } \\
\mathrm{mmol} / \mathrm{L}\end{array}$} & $\mathrm{F}$ & 0.22 & 0.18 & $0.20^{\mathrm{b}, \uparrow}$ & $0.24 \dagger$ & $0.12 \dagger$ & 0.02 & NS & 0.01 & 0.001 \\
\hline & $\mathrm{F}_{\mathrm{L}}$ & 0.21 & 0.15 & $0.25^{\mathrm{ab}, \dagger}$ & $0.23 \dagger$ & $0.19 \dagger$ & 0.03 & NS & NS & NS \\
\hline & $\mathrm{F}_{\mathrm{A}}$ & 0.28 & 0.20 & $0.35^{\mathrm{a}, \uparrow}$ & $0.34 \dagger$ & 0.26 & 0.05 & & & \\
\hline & $\mathrm{F}_{\mathrm{AL}}$ & 0.27 & 0.23 & $0.33^{\mathrm{ab}, \uparrow}$ & $0.29 \dagger$ & 0.26 & 0.04 & & & \\
\hline & $\mathrm{C}$ & 0.24 & 0.18 & 0.51 & 0.52 & 0.36 & 0.05 & & & \\
\hline \multirow[t]{5}{*}{$\begin{array}{l}\text { Glucose, } \\
\mathrm{mmol} / \mathrm{L}\end{array}$} & $\mathrm{F}$ & 3.46 & 5.01 & 4.67 & $4.48 \dagger$ & $4.25 \dagger$ & 0.30 & NS & NS & 0.001 \\
\hline & $\mathrm{F}_{\mathrm{L}}$ & 4.34 & 4.37 & 4.44 & 4.68 & $4.53 \dagger$ & 0.26 & NS & 0.05 & 0.01 \\
\hline & $\mathrm{F}_{\mathrm{A}}$ & 3.23 & 5.54 & 5.01 & 4.69 & $4.47 \dagger$ & 0.30 & & & \\
\hline & $\mathrm{F}_{\mathrm{AL}}$ & 3.93 & 5.44 & 4.83 & 4.86 & $4.64 \dagger$ & 0.24 & & & \\
\hline & $\mathrm{C}$ & 3.87 & 4.83 & 5.09 & 5.65 & 5.88 & 0.31 & & & \\
\hline
\end{tabular}

\footnotetext{
${ }^{\mathrm{a}, \mathrm{b}}$ Values with different superscript letters are significantly different $(P<0.05)$ among formula-fed groups.

${ }^{1}$ Within formula-fed groups, for all days, $\mathrm{L}=$ lactoferrin effect, $\mathrm{A}=$ vitamin $\mathrm{A}$ effect, $\mathrm{T}=$ time effect (age), $\mathrm{L} \times \mathrm{A}=$ lactoferrin $\times$ vitamin $\mathrm{A}$ interaction, $\mathrm{T} \times \mathrm{A}=$ vitamin $\mathrm{A} \times$ time interaction, and $\mathrm{T} \times \mathrm{L}=$ time $\times$ lactoferrin interaction.

$\dagger$ Values are significantly different $(P<0.05)$ between the formula-fed groups and the C-fed group.
}

been observed in earlier studies (Hadorn et al., 1997; Sauter et al., 2003). Compositions of F for $\mathrm{d} 1,2$, 3, and 4 were planned to be similar to those of their respective $\mathrm{C}$ milkings, but calves of group $\mathrm{C}$ ingested quantitatively more DM, CP, crude fat, gross energy, and ash and less nitrogen-free extract, vitamin $\mathrm{A}$, and Lf than F-fed calves. The Lf contents in $\mathrm{C}$ were lower than in studies of Tsuji et al. (1990) and Dawes et al. (2004), who found 2000 and $2200 \mathrm{mg} / \mathrm{L}$, respectively; of Nonnecke and Smith (1984), who measured $1800 \mathrm{mg} / \mathrm{L}$ at the onset of lactation; and of Blum and Hammon (2000), who measured 1800 and $900 \mathrm{mg} / \mathrm{L}$ in $\mathrm{C}$ milkings 1,2 (on $\mathrm{d} 1$ of lactation) and 500 and $400 \mathrm{mg} / \mathrm{L}$ in $\mathrm{C}$ milkings 3 and 4 (on d 2 of lactation). However, the analyzed colostral Lf values in the present study corresponded well with those of Hurley and Sixiang (2003), who measured 700 and $600 \mathrm{mg} / \mathrm{L}$ in $\mathrm{C}$ milkings 1 and 2 . Concentrations of Lf in the formulas were slightly higher than those in the corresponding colostrum. Reasons for differences of Lf content in C between the present study and other investigations are not known. Differences in breed, lactation number, health status of the udder, and stage of mammary involution, which are known to influence colostral Lf values (Nonnecke and Smith, 1984; Tsuji et al., 1990) were possible causes of variation.

Although it is known that vitamin A contents in C depend on several factors such as on intake, season (Konermann and Abou El Fadle, 1966), day of lactation (Johnston and Chew, 1984), and parity number of the dam (Franklin et al., 1998), pooled C contained amounts of vitamin A that were comparable with those of previous studies and declined with time as previously shown (Konermann and Abou El Fadle, 1966; Johnston and Chew, 1984). The amount of vitamin $\mathrm{A}$ in the $\mathrm{F}$ fed to calves was approximately 7 times the amount measured in $\mathrm{C}$.

\section{BW and Health Status}

The BW remained stable during the study period and did not change among groups, indicating that feed use in the different groups was similar. The increase of rectal temperature, observed in all groups during the experimental period, was in accordance with other studies (Kurz and Willett, 1991; Hadorn et al., 1997; Egli 
d 1

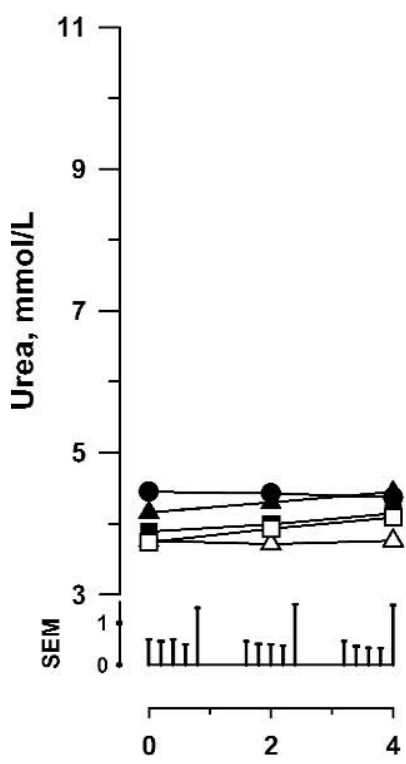

d 2

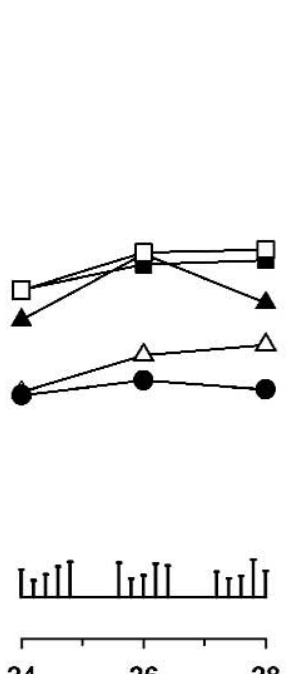

d 3 d 4

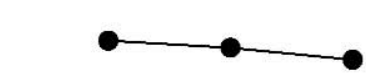

Цய
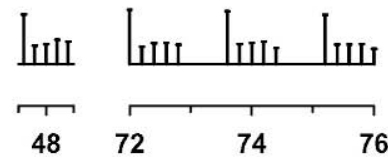

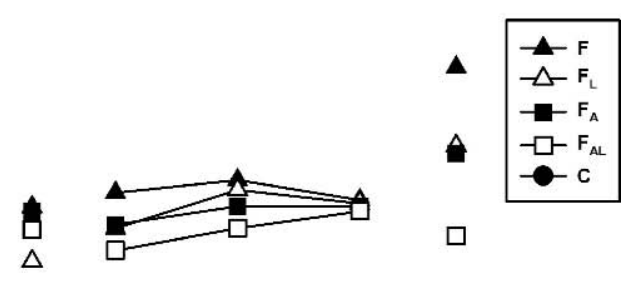

d 5

Time after first meal, $h$

Figure 4. Plasma urea concentrations in calves fed with formula $(F)$, formula plus vitamin $A\left(F_{A}\right)$, formula plus lactoferrin $\left(F_{L}\right)$, formula plus vitamin $\mathrm{A}$ and lactoferrin $\left(\mathrm{F}_{\mathrm{AL}}\right)$, or colostrum $(\mathrm{C})$. Blood samples were taken on $\mathrm{d} 1,2,3,4$, and 5 shortly before feed intake and on d 1,2 , and 4 additionally at 2 and $4 \mathrm{~h}$ after feed intake. Values are means; $\mathrm{n}=7$ per group.

Table 5. Preprandial plasma concentrations of hormonal traits for first $5 \mathrm{~d}$ of life of calves fed with formula $(\mathrm{F})$, formula plus vitamin $\mathrm{A}\left(\mathrm{F}_{\mathrm{A}}\right)$, formula plus lactoferrin $\left(\mathrm{F}_{\mathrm{L}}\right)$, formula plus vitamin $\mathrm{A}$ and lactoferrin $\left(\mathrm{F}_{\mathrm{AL}}\right)$, or colostrum (C). Values are means ( $\mathrm{n}=7$ per group) and pooled SEM.

\begin{tabular}{|c|c|c|c|c|c|c|c|c|c|c|}
\hline \multirow[b]{2}{*}{ Trait } & \multirow[b]{2}{*}{ Group } & \multirow[b]{2}{*}{ d 1} & \multirow[b]{2}{*}{$\mathrm{d} 2$} & \multirow[b]{2}{*}{ d 3} & \multirow[b]{2}{*}{ d 4} & \multirow[b]{2}{*}{ d 5} & \multirow[b]{2}{*}{ SEM } & \multicolumn{3}{|c|}{ ANOVA $(P)^{1}$} \\
\hline & & & & & & & & $\begin{array}{l}\mathrm{L} \\
\mathrm{L} \times \mathrm{A}\end{array}$ & $\begin{array}{l}\mathrm{A} \\
\mathrm{T} \times \mathrm{A}\end{array}$ & $\begin{array}{l}\mathrm{T} \\
\mathrm{T} \times \mathrm{L}\end{array}$ \\
\hline $\mathrm{GH}, \mu \mathrm{g} / \mathrm{L}$ & $\begin{array}{l}\mathrm{F} \\
\mathrm{F}_{\mathrm{L}} \\
\mathrm{F}_{\mathrm{A}} \\
\mathrm{F}_{\mathrm{AL}} \\
\mathrm{C}\end{array}$ & $\begin{array}{l}14.5 \\
12.0 \\
13.4 \\
17.8 \\
12.9\end{array}$ & \begin{tabular}{l|l}
27.1 & \\
24.6 & \\
28.6 & \\
22.8 & \\
28.7 &
\end{tabular} & $\begin{array}{l}28.4^{\mathrm{ab}} \\
18.9^{\mathrm{ab}} \\
40.9^{\mathrm{a}} \dagger \\
19.7^{\mathrm{b}} \\
18.0\end{array}$ & $\begin{array}{l}28.6 \\
23.7 \\
23.2 \\
14.2 \\
16.2\end{array}$ & $\begin{array}{l}31.8 \\
24.2 \\
22 \\
14.4 \\
21.8\end{array}$ & $\begin{array}{l}5.2 \\
4.9 \\
5.8 \\
4.1 \\
3.5\end{array}$ & $\begin{array}{l}\mathrm{NS}^{2} \\
\mathrm{NS}\end{array}$ & $\begin{array}{l}\mathrm{NS} \\
0.05\end{array}$ & $\begin{array}{l}0.001 \\
\text { NS }\end{array}$ \\
\hline Insulin, $\mu \mathrm{g} / \mathrm{L}$ & $\begin{array}{l}\mathrm{F} \\
\mathrm{F}_{\mathrm{L}} \\
\mathrm{F}_{\mathrm{A}} \\
\mathrm{F}_{\mathrm{AL}} \\
\mathrm{C}\end{array}$ & $\begin{array}{l}1.37^{\mathrm{abc}} \\
2.55^{\mathrm{acd}} \\
0.66^{\mathrm{abd}} \\
0.37^{\mathrm{bcd}, \dagger} \\
2.58\end{array}$ & $\begin{array}{l}0.71 \\
0.68 \\
0.71 \\
0.63 \\
0.60\end{array}$ & $\begin{array}{l}0.39 \\
0.32 \\
0.37 \\
0.26 \\
0.37\end{array}$ & $\begin{array}{l}0.30 \\
0.37 \\
0.22 \\
0.25 \\
0.37\end{array}$ & $\begin{array}{l}0.21 \\
0.29 \\
0.22 \\
0.19 \\
0.41\end{array}$ & $\begin{array}{l}0.17 \\
0.42 \\
0.11 \\
0.05 \\
0.44\end{array}$ & $\begin{array}{l}\text { NS } \\
\text { NS }\end{array}$ & $\begin{array}{l}\mathrm{NS} \\
0.05\end{array}$ & $\begin{array}{l}0.01 \\
\text { NS }\end{array}$ \\
\hline $\mathrm{T}_{3}, \mathrm{nmol} / \mathrm{L}$ & $\begin{array}{l}\mathrm{F} \\
\mathrm{F}_{\mathrm{L}} \\
\mathrm{F}_{\mathrm{A}} \\
\mathrm{F}_{\mathrm{AL}} \\
\mathrm{C}\end{array}$ & $\begin{array}{l}7.9 \\
9.2 \\
8.6 \\
8.1 \\
9.3\end{array}$ & $\begin{array}{l}4.4 \\
4.4 \\
5.1 \\
5.6 \\
6.4\end{array}$ & $\begin{array}{l}3.5 \\
3.7 \\
4.7 \\
4.8 \\
5.6\end{array}$ & $\begin{array}{l}2.7 \\
3 \\
3.6 \\
4.5 \\
4.8\end{array}$ & $\begin{array}{l}1.6 \\
2.2 \\
2.6 \\
3.2 \\
4\end{array}$ & $\begin{array}{l}0.6 \\
0.5 \\
0.5 \\
0.7 \\
1.3\end{array}$ & $\begin{array}{l}\text { NS } \\
\text { NS }\end{array}$ & $\begin{array}{l}\text { NS } \\
\text { NS }\end{array}$ & $\begin{array}{l}0.001 \\
\text { NS }\end{array}$ \\
\hline
\end{tabular}

a,b,c,d Values with different superscript letters are significantly different $(P<0.05)$ among formula-fed groups.

${ }^{1}$ Within formula-fed groups, $\mathrm{L}=$ lactoferrin effect, $\mathrm{A}=$ vitamin $\mathrm{A}$ effect, $\mathrm{T}=$ time effect (age), $\mathrm{L} \times \mathrm{A}=$ lactoferrin $\times$ vitamin $\mathrm{A}$ interaction, $\mathrm{T} \times \mathrm{A}=$ vitamin $\mathrm{A} \times$ time interaction, and $\mathrm{T} \times \mathrm{L}=$ time $\times$ lactoferrin interaction.

${ }^{2} P>0.05$.

$\dagger$ Values are significantly different $(P<0.05)$ between the formula-fed groups and the colostrum-fed group. 


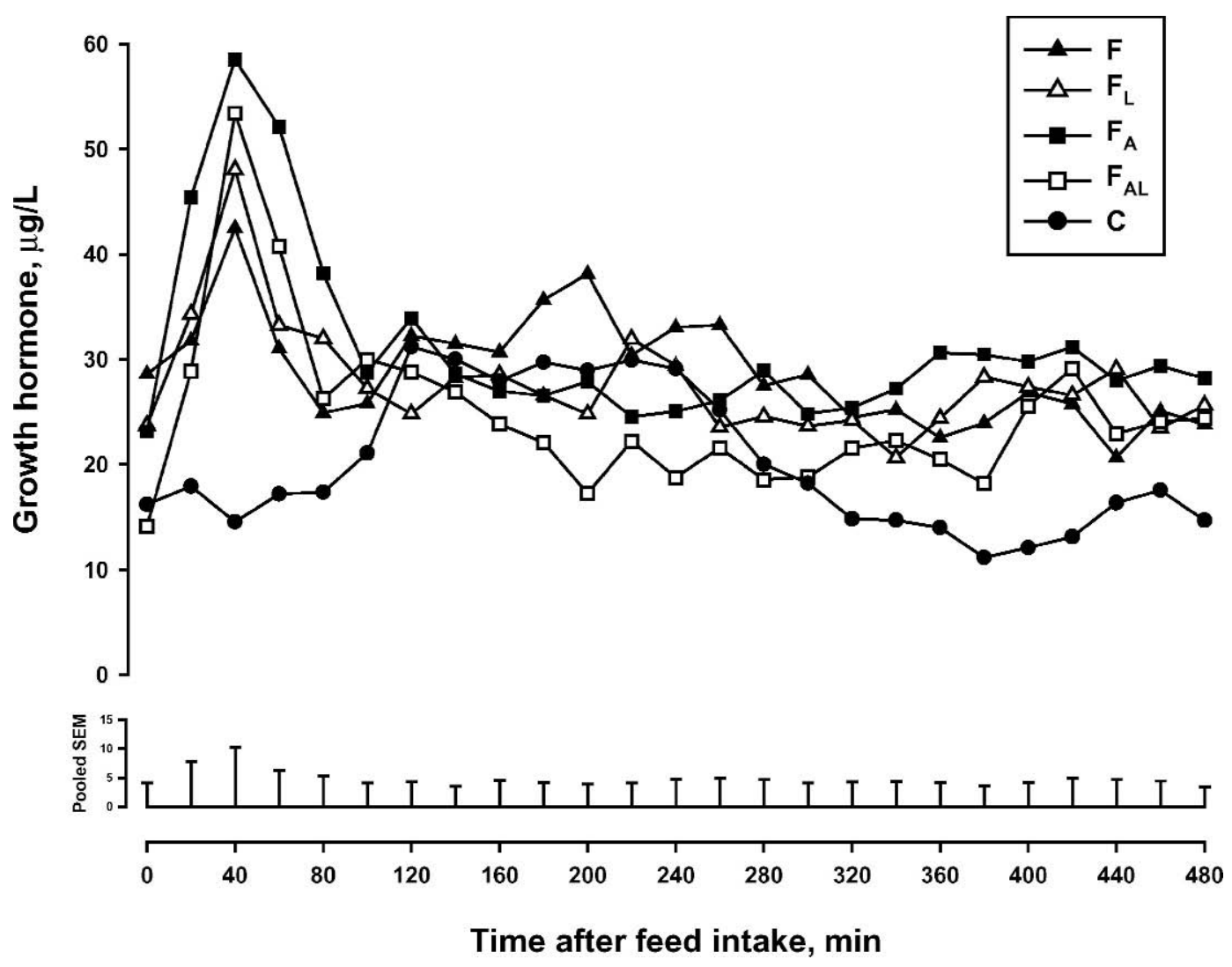

Figure 5. Plasma growth hormone concentrations in calves fed with formula $(F), F$ plus vitamin $A\left(F_{A}\right), F$ plus lactoferrin $\left(F_{L}\right), F$ plus vitamin $\mathrm{A}$ and lactoferrin $\left(\mathrm{F}_{\mathrm{AL}}\right)$, or with colostrum $(\mathrm{C})$. Blood samples were taken on d 4 from just before feed intake and then every 20 min for $8 \mathrm{~h}$. Values are means $( \pm \mathrm{SE}) ; \mathrm{n}=7$ per group. Standard errors of the means are represented by strokes aligned at the bottom of the figure for each corresponding time.

and Blum, 1998) and may be interpreted as a sign of increasing vitality and metabolic activity. Decreasing heart rate and relatively stable respiratory rates in the present study were also in accordance with previous studies (Kurz and Willett, 1991; Hadorn et al., 1997; Egli and Blum, 1998). Loose feces in F-fed calves from d 3 on expressed a mild disturbance of gastrointestinal tract function. However, there were no differences in other health traits among the different groups. We did not observe clinical symptoms that would have been typical for vitamin A deficiency (Eaton et al., 1970), likely because the present experiment was too short for the manifestation of those symptoms.

Decreases of the hematocrit, of hemoglobin concentrations, and of erythrocyte and segmented neutrophil numbers between on $\mathrm{d} 1$ and 5 in all calves were in accordance with other studies (Kurz and Willett, 1991; Egli and Blum, 1998) and are probably in part the result of a hemodilution. If so, the increase in the number of lymphocytes indicates an enhanced production at the bone marrow level. Hematocrits on $d 1$ were below the mean of the normal hematocrit value (Scheidegger, 1973; Egli and Blum, 1998). On d 5, the hematocrit and concentrations of hemoglobin and erythrocyte numbers were below the normal range, whereas numbers of leukocytes, neutrophils, monocytes, lymphocytes, and thrombocytes were in or above the normal range (Scheidegger, 1973; Kurz and Willett, 1991; Egli and Blum, 1998).

No differences in hematocrit, hemoglobin concentrations, and erythrocyte numbers were found among groups. This was in contrast to a study of Kume and Tanabe (1996) in which Lf administration increased the hematocrit from $\mathrm{d} 2$ to 10 and the hemoglobin concentration from d 1 to 10 of age. However, in the latter study, calves were also supplemented with iron, which was not the case in this study.

Based on blood $\mathrm{pH}$, the calves immediately after birth were slightly acidotic, as expected (Rosenberger, 1990), but on $\mathrm{d} 5$, values were in the normal range. The $\mathrm{pO}_{2}$ was low, and the $\mathrm{pCO}_{2}$ was high, whereas bicarbonate concentrations were in the normal range (Rosenberger, 
d 1

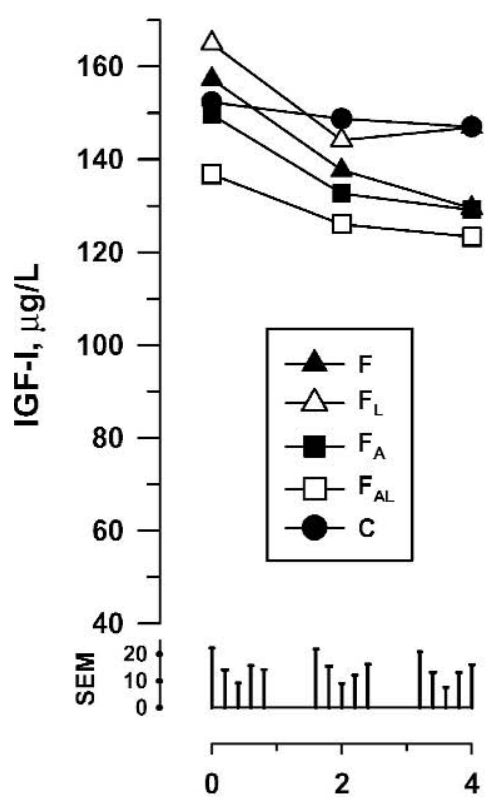

d 2
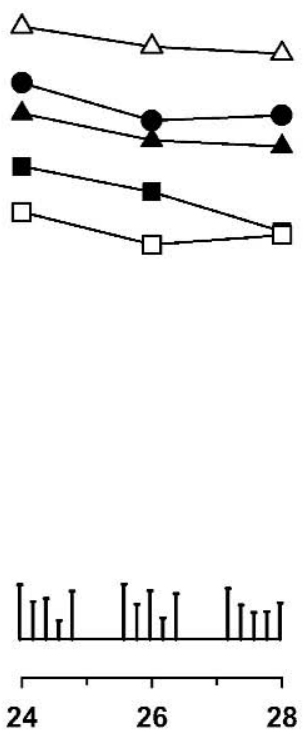

d 3

d 4 d 5
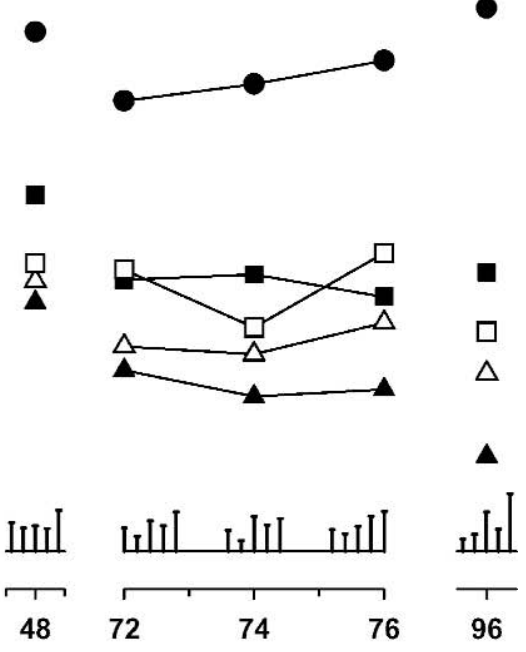

Time after first meal, $\mathbf{h}$

Figure 6. Plasma IGF-I concentrations in calves fed with formula $(F)$, formula plus vitamin $A\left(F_{A}\right)$, formula plus lactoferrin $\left(F_{L}\right)$, formula plus vitamin A and lactoferrin ( $\left.\mathrm{F}_{\mathrm{AL}}\right)$, or colostrum (C). Blood samples were taken on d 1, 2, 3, 4, and 5 shortly before feed intake and on $\mathrm{d}$ 1,2 , and 4 additionally at 2 and $4 \mathrm{~h}$ after feed intake. Values are means; $\mathrm{n}=7$ per group.

1990) on $d 1$ and increased up to $d 5$. Base excess increased from $\mathrm{d} 1$ to 5 , which can be interpreted as a means to correct the acidosis (Rosenberger, 1990).

\section{Blood Metabolites and Hormones}

In C-fed calves, plasma Lf concentrations transiently increased on $\mathrm{d} 1$ after the first meal, as shown in previous studies (Harada et al., 1999; Hurley and Sixiang, 2003; Taluker et al., 2003). In contrast, plasma Lf con- centrations did not rise in calves fed $\mathrm{F}_{\mathrm{L}}$, and among $\mathrm{F}$ fed calves, concentrations were surprisingly similar. The causes for the obvious lack in Lf absorption from $\mathrm{F}$ are not known. Orally administered Lf in neonates is absorbed in the intestine via endocytosis, appears into the circulation (as shown in humans, piglets, and calves), and can even appear in the cerebrospinal fluid, as shown in calves (Taluker et al., 2003), followed by excretion via the urine and the bile (Masson et al., 1966; Hutchens et al., 1991). Possibly, other proteins and pep-

Table 6. Preprandial plasma insulin-like growth factor binding protein (IGFBP)-2 and -3 and IGFBP-2 to IGFBP-3 ratios on $d 5$ of neonatal calves fed with formula $(\mathrm{F})$, formula plus vitamin $\mathrm{A}\left(\mathrm{F}_{\mathrm{A}}\right)$, formula plus lactoferrin $\left(\mathrm{F}_{\mathrm{L}}\right)$, formula plus vitamin $\mathrm{A}$ and lactoferrin $\left(\mathrm{F}_{\mathrm{AL}}\right)$, or colostrum $(\mathrm{C})$. Values are means $(\mathrm{n}=7$ per group) and pooled SEM. Units of IGFBP-2 and -3 are optical density on Western blots $\times 10^{3}$.

\begin{tabular}{|c|c|c|c|c|c|c|c|c|c|}
\hline \multirow[b]{2}{*}{ Trait } & \multicolumn{5}{|c|}{ Group } & \multirow[b]{2}{*}{ SE } & \multicolumn{3}{|c|}{$\operatorname{ANOVA}(P)^{1}$} \\
\hline & $\mathrm{F}$ & $\mathrm{F}_{\mathrm{L}}$ & $\mathrm{F}_{\mathrm{A}}$ & $\mathrm{F}_{\mathrm{AL}}$ & $\mathrm{C}$ & & $\mathrm{L}$ & $\mathrm{A}$ & $\mathrm{L} \times \mathrm{A}$ \\
\hline IGFBP-2 & 157 & 164 & 156 & 164 & 129 & 13 & $\mathrm{NS}^{2}$ & NS & NS \\
\hline IGFBP-3 & 110 & 137 & 141 & 146 & 153 & 12 & NS & $\dagger$ & NS \\
\hline IGFBP-2:IGFBP-3 & $1.5^{*}$ & 1.2 & 1.2 & 1.2 & 0.9 & 0.1 & NS & NS & NS \\
\hline
\end{tabular}

${ }^{1}$ Within formula-fed groups, $\mathrm{L}=$ lactoferrin effect, $\mathrm{A}=$ vitamin $\mathrm{A}$ effect, and $\mathrm{L} \times \mathrm{A}=$ lactoferrin $\times$ vitamin A interaction.

${ }^{2} P>0.05$.

$\dagger \mathrm{P}<0.1$.

*Values are significantly different $(P<0.05)$ between formula-fed groups and the C-fed group. 
tides and also calcium (Wang and Hurley, 1998) in F might have interacted with Lf absorption. Consequently, biological effects could not be expected, and there were, in fact, only time-dependent associations of Lf with hematocrit, hemoglobin concentrations, number of erythrocytes, and preprandial glucose concentrations.

Plasma concentrations of vitamin A at birth were low in calves of all groups and similar to those reported in other studies (Blum et al., 1997; Franklin et al., 1998; Zanker et al., 2000). Concentrations increased in C-fed calves, as expected (Blum et al., 1997; Zanker et al., 2000). Concentrations increased slightly (albeit significantly) less in calves that were fed $\mathrm{F}_{\mathrm{A}}$ than in $\mathrm{C}$-fed calves. Because these $\mathrm{F}$-fed groups were fed considerably higher amounts of vitamin A than those of group $\mathrm{C}$, the absorption efficiency of vitamin A was likely much greater in $\mathrm{C}$-fed calves than in $\mathrm{F}_{\mathrm{A}}$-fed calves. It cannot be excluded, however, that beta-carotene, the retinol precursor that is expected to be present in much higher amounts in $\mathrm{C}$ than in $\mathrm{F}$ based on previous reports (Blum et al., 1997; Zanker et al., 2000), was absorbed and converted to some extent to vitamin A, thus improving the vitamin A status. High retinol levels significantly affected the $\mathrm{Hb}$ concentration, tended to affect IGFBP-3 levels on d 5, and were associated with increased postprandial TG concentrations from d 3 to 5 . On the other hand, concentrations remained low or even decreased in calves fed $\mathrm{F}$ without added vitamin $\mathrm{A}$. Although plasma retinol levels may not mirror hepatic vitamin A stores until reaching a minimum value (Swanson et al., 2000; Zanker et al., 2000), the calves fed $\mathrm{F}$ without vitamin $\mathrm{A}$ appear to be vitamin A deficient (Eaton et al., 1970).

Higher total protein concentrations in blood plasma of $\mathrm{C}$-fed than in $\mathrm{F}$-fed calves after the first meal can be explained by a higher Ig absorption compared with Ffed calves (Hadorn et al., 1997; Egli and Blum, 1998; Rauprich et al., 2000). In contrast, preprandial albumin concentrations remained relatively stable during the whole study, but decreased postprandially, as shown previously (Hadorn et al., 1997).

Higher blood urea concentrations in F-fed than in Cfed calves were in accordance with previous studies (Rauprich et al., 2000). Causes for higher levels in Ffed than in C-fed calves are not clear. Because slightly higher amounts of protein were provided to calves of group $\mathrm{C}$ than in $\mathrm{F}$-fed groups, protein excess can be excluded in F-fed calves as a cause of high urea levels. There was also no obvious evidence for impaired kidney function in these latter groups. An enhanced breakdown of endogenous proteins can therefore be postulated. In addition, a lower protein synthesis relative to protein ingestion in $\mathrm{F}$-fed than $\mathrm{C}$-fed calves might have contributed to enhanced urea levels. Indeed, rates of fractional protein synthesis in liver, pancreas, kidney, spleen, and skeletal muscle in piglets are enhanced by $\mathrm{C}$ intake and this has been attributed to the effects of ingested and absorbed colostral bioactive substances, such as IGF and Lf (Burrin et al., 1992, 1996). Based on these findings, higher plasma IGF-I and Lf concentrations in $\mathrm{C}$-fed calves than in F-fed calves might have contributed to lower urea levels through stimulation of anabolic protein metabolism.

Lower triglyceride concentrations from $\mathrm{d} 3$ on in F-fed than in C-fed calves were in accordance with previous studies (Blum et al., 1997; Hammon and Blum, 1998; Rauprich et al., 2000). The vitamin A status in the present study had a positive effect on plasma triglyceride levels on $\mathrm{d} 3$, which is in accordance with the reports that vitamin A (specifically retinoic acid or retinyl acetate) enhances plasma triclyceride levels in rats (Solomon and Erdman, 1980) and in chickens (Sklan, 1983) through an increase of plasma free fatty acids and of hepatic triglyceride synthesis and secretion (not measured in the present study) (Singh et al., 1969; Sklan, 1983).

High NEFA concentrations at birth were likely and at least in part the consequence of enhanced lipolysis caused by increased sympathomedullary activity (Steinhardt et al., 1995). Concentrations decreased postprandially and similarly in all groups during the whole study, as shown previously (Hadorn et al., 1997; Egli and Blum, 1998; Rauprich et al., 2000). Nonesterified fatty acid concentrations are well known to be sensitive indicators of the energy intake in neonatal calves (Hadorn et al., 1997). However, because there were no significant differences in NEFA concentrations among groups, differences in energy intake between $\mathrm{F}$-fed calves and C-fed calves were likely not sufficient to have an influence on NEFA concentrations.

Glucose concentrations transiently increased postprandially (data not shown), as shown repeatedly before (Hadorn et al., 1997; Blum and Hammon, 2000; Rauprich, et al., 2000). In contrast, preprandial glucose concentrations remained relatively stable from $d 1$ to 5 within groups. Ingested amounts of nitrogen-free extract were slightly lower in F-fed groups than in C-fed groups, and glucose concentrations on $\mathrm{d} 4$ and 5 were accordingly significantly higher in the $\mathrm{C}$-fed group. It has previously been shown that $\mathrm{C}$-fed calves after a few days following birth maintain higher glucose levels than milk- or F-fed calves, possibly as a consequence of enhanced gluconeogenesis (Hadorn et al., 1997; Hammon and Blum, 1998; Hammon et al., 2003).

On $\mathrm{d} 4$, basal GH concentrations in 3 of the $4 \mathrm{~F}$-fed groups were higher than in C-fed calves. In addition, GH concentrations transiently increased on d 4 just 
after feed intake in F-fed calves (with the exception of group F), in contrast to group $\mathrm{C}$. There are various possibilities that may explain these differences. The IGF-I exerts a negative effect on GH secretion in neonatal calves (Hammon and Blum, 1997; Sauter et al., 2003). Therefore, the higher IGF-I concentrations observed on $\mathrm{d} 4$ in $\mathrm{C}$-fed than in $\mathrm{F}$-fed calves could explain the relatively low $\mathrm{GH}$ concentrations in group $\mathrm{C}$. The ratio of GH to IGF-I concentrations in plasma was reduced by $\mathrm{C}$ feeding and because a low GH to IGF-I ratio reflects an enhanced degree of maturation of the somatotropic axis (Gluckman et al., 1999; Sauter et al., 2003), C intake likely enhanced the maturation of the GH-IGF-I axis compared with F intake. Slight differences in ingested fat composition and amounts fed in $\mathrm{F}$ vs. C might have additionally influenced GH levels (Coxam et al., 1989). Moreover, plasma TG concentrations (data not shown) were simultaneously higher in group $\mathrm{C}$ than in $\mathrm{F}$-fed calves. As demonstrated by Coxam et al. (1989), an increase in plasma TG concentrations inhibits GRF-mediated GH secretion in calves. Vitamin A in the present experiment did not increase GH concentrations as was expected based on other studies (Evain-Brion et al., 1994; Raifen et al., 1996). However, as none of these studies was carried out with neonates, it was possible that the immature somatotropic axis of neonatal calves (Hammon and Blum, 1997; Sauter et al., 2003) reacts differently than in mature animals.

Concentrations of IGF-I decreased especially in Ffed calves, as shown previously (Hadorn et al., 1997; Zanker et al., 2000), and were higher in C-fed calves than in F-fed calves from d 3 on. The IGF-I status markedly depends on energy and protein intake, as also shown in calves (Hadorn et al., 1997; Hammon and Blum, 1997, 1998). Because F- and C-fed calves received slightly different amounts of energy and protein, differences of IGF-I concentrations between F-fed and C-fed calves were likely also due to these factors. Furthermore, it is known that other factors can influence the production of IGF-I. As previously shown, F contains very low concentrations of nonnutrient factors that may influence plasma IGF-I levels (Blum and Hammon, 2000; Blum and Baumrucker, 2002), and there is agreement that colostral IGF-I is barely, if at all absorbed (Vacher et al., 1995; Hammon and Blum, 1997; Blum and Baumrucker, 2002). Higher IGF-I plasma levels in C-fed than F-fed calves were associated with corresponding elevations of IGFBP-3, the main IGF-I binding protein in neonatal calves (Skaar et al., 1994). Higher IGFBP-2 to IGFBP-3 ratios in group F than in group $\mathrm{C}$ were in accordance with previous studies in neonatal calves (Hammon and Blum, 1997; Hammon et al., 2000) and probably resulted in an enhanced clear- ance rate of IGF-I from blood circulation because IGFBP-2 leaves capillaries, in contrast to IGFBP-3. Based on studies in the bovine mammary gland, we expected interactions of Lf and vitamin A concentrations with IGFBP-3 levels, the main IGF binding protein in neonatal calves (Skaar et al., 1994) and thus with IGF-I concentrations (Baumrucker and Erondu, 2000; Blum and Baumrucker, 2002). Although the supplementation of Lf had no effect because of the unexpected lack of Lf absorption, vitamin A supplementation within F-fed calves tended to affect plasma IGF-I levels. In accordance, vitamin A deficiency in the Japanese quail and the rat was associated with decreased plasma IGF-I concentrations, in the Japanese quail combined with reduced IGF-I mRNA expression in several tissues (Fu et al., 2001, 2002). Vitamin A also tended to influence IGFBP-3 concentrations, in agreement with the situation in the bovine mammary gland (Baumrucker and Erondu, 2000) and in growing children (Raifen et al., 1996).

Causes for different preprandial insulin concentrations among groups are not known. Three calves had extremely high preprandial insulin concentrations. A postprandial transient rise was observed (data not shown), as expected (Hadorn et al., 1997; Hammon and Blum, 1997). Insulin concentrations on d 5 were numerically, but not significantly, higher than in F-fed groups, and this mirrored plasma concentrations of glucose.

Concentrations of $\mathrm{T}_{3}$ during the entire study decreased, as expected (Hadorn et al., 1997; Egli and Blum, 1998; Hammon and Blum, 1998). Plasma $T_{3}$ levels in growing cattle sensitively react to differences in energy intake (Blum et al., 1985), although evidence for this correlation in the neonatal calf is still lacking (Hadorn et al., 1997). Nevertheless, the absence of group differences indicates that the $\mathrm{T}_{3}$-dependent metabolic rate was likely similar in different groups.

In conclusion, metabolite and hormone concentrations of neonatal calves were variably influenced by feeding $\mathrm{C}$ containing naturally high amounts of $\mathrm{Lf}$ and vitamin $\mathrm{A}$ or by feeding $\mathrm{F}$ without or with added $\mathrm{Lf}$ and (or) vitamin $\mathrm{A}$. The addition of vitamin $\mathrm{A}$ to the $\mathrm{F}$ influenced plasma concentrations of vitamin A, hemoglobin, and triglycerides and tended to affect IGFBP-3 levels of neonatal calves, but vitamin $\mathrm{A}$ fed with the $\mathrm{F}$ was obviously less well used than if fed C. Lactoferrin added to the $\mathrm{F}$ surprisingly did not significantly influence the plasma Lf status, whereas colostral Lf was obviously readily absorbed and apperaed in the circulation of neonatal calves. Vitamin A and Lf under the chosen experimental conditions did not interact with respect to the IGF-I and IGFBP-3 status. It remains to be shown whether other experimental situations can 
show interactions between Lf, vitamin A, IGFBP-3, and IGF-I in neonatal calves.

\section{ACKNOWLEDGMENTS}

This study was supported by Swiss National Science Foundation (grant \# 32-6705.01). We thank Y. Aeby and his staff at Agroscope Posieux-Liebefeld, Switzerland, for putting calves at our disposal and E. Husman (UFA AG, Sursee, Switzerland) for helping us to develop milk-based formulas. We also thank Claudine Morel, Chantal Philipona, and Yolande Zbinden (Division of Animal Nutrition and Physiology, Vetsuisse Faculty, University of Berne, Switzerland) for their excellent laboratory work.

\section{REFERENCES}

Baumrucker, C. R., and N. E. Erondu. 2000. Insulin-like growth factor (IGF) system in the bovine mammary gland and milk. J. Mammary Gland Biol. Neoplasia 5:53-54.

Blum, J. W., and C. R. Baumrucker. 2002. Colostral and milk insulinlike growth factors and related substances: Mammary gland and neonatal (intestinal and systemic) targets. Domest. Anim. Endocrinol. 23:101-110.

Blum, J. W., U. Hadorn, H. P. Sallmann, and W. Schuep. 1997. Delaying colostrum intake by one day impairs plasma lipid, essential fatty acid, carotene, retinol and alpha-tocopherol status in neonatal calves. J. Nutr. 127:2024-2029.

Blum, J. W., and H. M. Hammon. 2000. Colostrum effects on the gastrointestinal tract, and on nutritional, endocrine and metabolic parameters in neonatal calves. Livest. Prod. Sci. 66:151-159.

Blum, J. W., W. Schnyder, P. L. Kunz, A. K. Blom, H. Bickel, and A. Schürch. 1985. Reduced and compensatory growth: Endocrine and metabolic changes during food restriction and refeeding in steers. J. Nutr. 115:417-424.

Buetikofer, U., and J. O. Bosset. 1994. HPLC-Bestimmungsmethoden in der Qualitätskontrolle von Milch und Milchprodukten. Mitt. Gebiete Lebensm. Hyg. 85:594-607.

Burrin, D. G., R. J. Shulman, P. J. Reeds, T. A. Davis, and K. R. Gravitt. 1992. Porcine colostrum and milk stimulate visceral organ and skeletal muscle protein synthesis in neonatal piglets. J. Nutr. 122:1205-1213.

Burrin, D. G., H. Wang, J. Heath, and M. A. Dudley. 1996. Orally administered lactoferrin increases hepatic protein synthesis in formula-fed newborn pigs. Pediatr. Res. 40:72-76.

Coxam, V., M.-J. Davicco, and J.-P. Barlet. 1989. Effects of triglycerides on growth hormone (GH)-releasing factor-mediated $\mathrm{GH}$ secretion in newborn calves. Domest. Anim. Endocrinol. 6:389-393.

Dawes, M. E., J. Lakritz, J. W. Tyler, M. Cockrell, A. E. Marsh, D. M. Estes, R. L. Larson, and B. Steevens. 2004. Effects of supplemental lactoferrin on serum lactoferrin and IgG concentrations and neutrophil oxidative metabolism in Holstein calves. J. Vet. Intern. Med. 18:104-108.

Eaton, H. D., J. J. Lucas, S. W. Nielsen, and C. F. Helmboldt. 1970. Association of plasma or liver vitamin A concentrations with the occurrence of parotid duct metaplasia or of ocular papilledema in Holstein male calves. J. Dairy Sci. 53:1775-1779.

Egli, C. P., and J. W. Blum. 1998. Clinical, haematological, metabolic and endocrine traits during the first three months of life of suckling Simmentaler calves held in a cow-calf operation. J. Vet. Med. A 45:99-118.

Evain-Brion, D., D. Porquet, P. Thérond, A. Fjellestad-Paulsen, M.O. Grenèche, L. Franx̧ois, and P. Czernichow. 1994. Vitamin A deficiency and noctural growth hormone secretion in short children. Lancet 343:87-88.
Franklin, S. T., C. E. Sorenson, and D. C. Hammell. 1998. Influence of vitamin A supplementation in milk on growth, health, concentrations of vitamins in plasma, and immune parameters of calves. J. Dairy Sci. 81:2623-2632.

Fu, Z., T. Noguchi, and H. Kato. 2001. Vitamin A deficiency reduces insulin-like growth factor (IGF-I) gene expression and increases IGF-I receptor and insulin receptor gene expression in tissues of Japanese Quail (Coturnix coturnix japonica). J. Nutr. 131:1189-1194.

Fu, Z., M. Yoneyama, T. Noguchi, and H. Kato. 2002. Response of the insulin-like growth factor system to vitamin A depletion and repletion in rats. J. Nutr. Sci. Vitaminol. 48:453-460.

Gluckman, P. D., S. V. Sizonenko, and N. S. Bassett. 1999. The transition from fetus to neonate-an endocrine perspective. Acta Paediatr. Suppl. 88:7-11.

Hadorn, U., H. M. Hammon, R. M. Bruckmeier, and J. W. Blum. 1997. Delaying colostrum intake by one day has important effects on metabolic traits and on gastrointestinal and metabolic hormones in neonatal calves. J. Nutr. 127:2011-2023.

Hammon, H. M., and J. W. Blum. 1997. The somatotropic axis in neonatal calves can be modulated by nutrition, growth hormone, and Long-R3-IGF-I. Am. J. Physiol. 273:E130-E138.

Hammon, H. M., and J. W. Blum. 1998. Metabolic and endocrine traits of neonatal calves are influenced by feeding colostrum for different durations or only milk replacer. J. Nutr. 128:624-632.

Hammon, M., S. N. Sauter, M. Reist, Y. Zbinden, C. Philipona, C. Morel, and J. W. Blum. 2003. Dexamethasone and colostrum feeding affect hepatic gluconeogenic enzymes differently in neonatal calves. J. Anim. Sci. 81:3095-3106.

Hammon, H. M., I. A. Zanker, and J. W. Blum. 2000. Delayed colostrum feeding affects IGF-I and insulin plasma concentrations in neonatal calves. J. Dairy Sci. 83:85-92.

Harada, E., Y. Itoh, K. Sitizyo, T. Takeuchi, Y. Araki, and H. Kitagawa. 1999. Characteristic transport of lactoferrin from the intestinal lumen into the bile via the blood in piglets. Comp. Biochem. Physiol. A Mol. Integr. Physiol. 124:321-327.

Hurley, W., and Z. Sixiang. 2003. Absorption of colostral lactoferrin in newborn calves. [Online.] http://traill.outreach.uiuc.edu/ dairynet/paperDisplay.cfm.ContentID=322. Accessed Apr. 19, 2004.

Hutchens, T. W., J. F. Henry, T. T. Yip, D. L. Hachey, R. J. Schanler, K. J. Motil, and C. Garza. 1991. Origin of intact lactoferrin and its DNA-binding fragments found in the urine of human milkfed preterm infants. Evaluation by stable isotopic enrichment. Pediatr. Res. 29:243-250.

Johnston, L. A., and B. P. Chew. 1984. Peripartum changes of plasma and milk vitamin A and beta-carotene among dairy cows with or without mastitis. J. Dairy Sci. 67:1832-1840.

Konermann, H., and W. Abou El Fadle. 1966. Zur Bedeutung von Karotin und Vitamin A für die Darmerkrankungen der Saugkälber. Dtsch. Tieraerztl. Wschr. 73:543-546.

Kume, S., and S. Tanabe. 1996. Effect of supplemental lactoferrin with ferrous iron on iron status of newborn calves. J. Dairy Sci. 79:459-464.

Kurz, M. M., and L. B. Willett. 1991. Carbohydrate, enzyme and hematology dynamics in newborn calves. J. Dairy Sci. 74:2109-2118.

Masson, P. L., J. F. Heremans, and C. Dive. 1966. An iron-binding protein common to many external secretions. Clin. Chim. Acta 14:735-739.

Merriam, G. R., and K. W. Wachter. 1982. Algorithms for the study of episodic hormone secretion. Am. J. Physiol. 243:E310-E318.

Nonnecke, B. J., and K. L. Smith. 1984. Biochemical and antibacterial properties of bovine secretion during mammary involution and at parturition. J. Dairy Sci. 67:2863-2872.

Raifen, R., Y. Altman, and Z. Zadik. 1996. Vitamin A levels and growth hormone axis. Horm. Res. 46:279-281.

Rauprich, A. B., H. M. Hammon, and J. W. Blum. 2000. Effects of feeding colostrum and a formula with nutrient contents as colostrum on metabolic and endocrine traits in neonatal calves. Biol. Neonate 78:53-64. 
Rosenberger, G. 1990. Pages 171-241 in Die klinische Untersuchung des Rindes. 3. Verlag. Verlag Paul Parey, Berlin und Hamburg, Germany.

SAS User's Guide: Statistics. 1994. SAS Inst., Inc., Cary, NC.

Sauter, S. N., E. Ontsouka, B. Roffler, Y. Zbinden, C. Philipona, M. Pfaffl, B. H. Breier, J. W. Blum, and H. M. Hammon. 2003. Effects of dexamethasone and colostrum intake on the somatotropic axis in neonatal calves. Am. J. Physiol. Endocrinol. Metab. 285:E252-E261.

Scheidegger, H. R. 1973. Veränderungen des roten Blutbildes und der Serumeisenkonzentration bei Simmentalerkaelbern. Schweiz. Arch. Tierheilkde. 115:483-497.

Singh, V. N., M. Singh, and T. A. Venkitasubramanian. 1969. Early effects of feeding excess vitamin A: Mechanism of fatty liver production in rats. J. Lipid Res. 10:395-401.

Skaar, T. C., C. R. Baumrucker, D. R. Deaver, and J. W. Blum. 1994. Diet effects and ontogeny of alterations of circulating insulin-like growth factor binding proteins in newborn dairy calves. J. Anim. Sci. 72:421-427.

Sklan, D. 1983. Effects of high vitamin A or tocopherol intake on hepatic lipid metabolism and intestinal absorption and secretion of lipids and bile acids in the chick. Br. J. Nutr. 50:409-416.

Söderhjelm, P., and B. Andersson. 1978. Simultaneous determination of vitamin $\mathrm{A}$ and vitamin $\mathrm{E}$ in feeds and foods by reverse phase high-pressure liquid-chromatography. J. Sci. Food Agric. 29:697-702.

Solomon, L. W., and J. W. Erdman, Jr. 1980. Vitamin A induced hypertriglyceridemia in cholesterol-fed rats. Lipids 15:157-162.
Steinhardt, M., H.-H. Thielscher, R. von Horn, T. von Horn, K. Ermgassen, and J. Ladewig. 1995. Anpassungsreaktionen von Milchrindkälbern in den ersten Lebenstagen. Tierarztl. Prax. 23:243-249.

Swanson, K. S., N. R. Merchen, J. W. Erdman, Jr., J. K. Drackley, F. Orias, D. E. Morin, and M. F. Haddad. 2000. Influence of dietary vitamin A content on serum and liver vitamin A concentrations and health in preruminant Holstein calves fed milk replacer. J. Dairy Sci. 83:2027-2036.

Taluker, J., T. Takeuchi, and E. Harada. 2003. Receptor-mediated transport of lactoferrin into the cerebrospinal fluid via plasma in young calves. J. Vet. Med. Sci. 65:957-964.

Tsuji, S., Y. Hirata, and F. Mukai. 1990. Comparison of lactoferrin content in colostrum between different cattle breeds. J. Dairy Sci. $73: 125-128$

Vacher, P.-Y., G. Bestetti, and J. W. Blum. 1995. Insulin-like growth factor I absorption in the jejunum of neonatal calves. Biol. Neonate 68:354-367.

Van Merris, V., E. Meyer, K. De Wasch, and C. Burvenich. 2002. Simple quantification of endogenous retinoids in bovine serum by high-performance liquid chromatography - diode-array detection. Anal. Chim. Acta 468:237-244.

Wang, H., and W. L. Hurley. 1998. Identification of lactoferrin complexes in bovine mammary secretions during mammary gland involution. J. Dairy Sci. 81:1896-1903.

Zanker, I. A., H. M. Hammon, and J. W. Blum. 2000. Beta-carotene, retinol and alpha-tocopherol status in calves fed the first colostrum at $0-2,6-7,12-13$ or 24-25 hours after birth. Int. J. Vitam. Nutr. Res. 70:305-310. 